Spectral properties of Sb IV from MCDHF calculations

This article has been downloaded from IOPscience. Please scroll down to see the full text article.

2012 J. Phys. B: At. Mol. Opt. Phys. 45165002

(http://iopscience.iop.org/0953-4075/45/16/165002)

View the table of contents for this issue, or go to the journal homepage for more

Download details:

IP Address: 130.235.64.24

The article was downloaded on 17/12/2012 at 08:54

Please note that terms and conditions apply. 


\title{
Spectral properties of Sb IV from MCDHF calculations
}

\author{
P Jönsson ${ }^{1}$, S Verdebout ${ }^{2}$ and G Gaigalas ${ }^{3,4}$ \\ ${ }^{1}$ School of Technology, Malmö University, 205-06 Malmö, Sweden \\ ${ }^{2}$ Chimie Quantique et Photophysique, CP160/09, Université Libre de Bruxelles, Av. FD Roosevelt 50, \\ B-1050 Brussels, Belgium \\ ${ }^{3}$ Vilnius University Research Institute of Theoretical Physics and Astronomy, A Goštauto 12, \\ LT-01108 Vilnius, Lithuania \\ ${ }^{4}$ Lithuanian University of Educational Sciences, Studentu̧ 39, LT-08106 Vilnius, Lithuania \\ E-mail: per.jonsson@mah.se and sverdebo@ulb.ac.be
}

Received 10 May 2012, in final form 18 June 2012

Published 16 July 2012

Online at stacks.iop.org/JPhysB/45/165002

\begin{abstract}
We report on extensive relativistic multiconfiguration Dirac-Hartree-Fock (MCDHF) spectrum calculations for Sb IV. Energies, $L S$-compositions and Landé $g_{J}$-factors for 60 oddand even-parity states are computed along with lifetimes and rates for transitions between these states. Results for the $5 \mathrm{~s}^{2}{ }^{1} \mathrm{~S}_{0}-5 \mathrm{~s} 5 \mathrm{p}^{3} \mathrm{P}_{0}^{\mathrm{o}}$ hyperfine-induced transition are also presented. Valence and core-valence electron correlation effects are accounted for by explicit configuration interaction. The calculated energies agree very well with experiment, but the labelling of some of the odd states is ambiguous due to close degeneracies between the $5 \mathrm{p} 5 \mathrm{~d}$, $5 \mathrm{~s} 7 \mathrm{p}$ and $5 \mathrm{p} 6 \mathrm{~s}$ configurations. Computed lifetimes of the excited states are compared with values from cascade-corrected beam-foil measurements.
\end{abstract}

\section{Introduction}

Three-times ionized antimony (Sb IV) belongs to the $\mathrm{Cd}$ isoelectronic sequence and the ground state is $5 \mathrm{~s}^{2}{ }^{1} \mathrm{~S}_{0}$. A revised and extended analysis by Rana et al [1] established 48 low lying levels. Based on multiconfiguration HartreeFock calculations with relativistic corrections (HFR) and leastsquares-fitting (LSF) calculations, the same authors predicted some additional eight level positions. Pinnington et al [2] performed decay-curve analysis, incorporating the arbitrarily normalized decay curve (ANDC) method to correct for cascade effects, on beam-foil spectra to derive lifetimes for nine upper states involved in the resonance transitions.

On the theoretical side, work has been devoted to the allowed and spin-forbidden $5 \mathrm{~s}^{2}{ }^{1} \mathrm{~S}-5 \mathrm{~s} 5 \mathrm{p}{ }^{1,3} \mathrm{P}_{1}^{\mathrm{o}}$ transitions, but comparatively little is known for more excited states. Migdalek and Baylis [3] used a limited relativistic configuration mixing and a polarization model to obtain rates of $5 \mathrm{~s}^{2}{ }^{1} \mathrm{~S}-5 \mathrm{~s} 5 \mathrm{p}{ }^{1,3} \mathrm{P}_{1}^{\mathrm{o}}$ in the Cd isoelectronic sequence. Chou and Huang [4] applied the multiconfiguration relativistic random-phase approximation on the same transitions. Other theoretical results are due to Lavin et al [5] who used the relativistic quantum defect orbital method with and without an explicit account for corevalence correlation with the singlet-singlet transition and to
Biémont et al [6] who used the relativistic Hartree-Fock approach, including a core-polarization potential, and the multiconfiguration Dirac-Fock method, taking the valence and core-valence correlation effects into account.

The purpose of this work is to improve and complement the dataset for $\mathrm{Sb} I V$, especially for the more excited states, and to explore the capacity of the GRASP2K multiconfiguration Dirac-Hartree-Fock (MCDHF) package [7, 8] to predict transition rates in 'spectrum calculations' including states high up in the Rydberg series. Sb IV remains a challenge due to close degeneracies between the $5 \mathrm{p} 5 \mathrm{~d}, 5 \mathrm{~s} 7 \mathrm{p}$ and $5 \mathrm{p} 6$ s odd-parity configurations. To facilitate a comparison with experimental data in this case, a transformation between the $j j$ - and $L S J$ coupling schemes becomes crucial $[9,10]$.

\section{Computational procedure}

The relativistic MCDHF method is described in great detail in a recent book by Grant [11]. Here we just give a brief outline of the method. Starting from the Dirac-Coulomb Hamiltonian for an $N$-electron system

$$
H_{\mathrm{DC}}=\sum_{i=1}^{N}\left(c \boldsymbol{\alpha}_{i} \cdot \boldsymbol{p}_{i}+\left(\beta_{i}-1\right) c^{2}+V_{i}^{N}\right)+\sum_{i>j}^{N} \frac{1}{r_{i j}},
$$


where $V^{N}$ is the monopole part of the electron-nucleus Coulomb interaction, the atomic state functions (ASFs) describing the studied fine-structure states are obtained as linear combinations of symmetry adapted configuration state functions (CSFs),

$$
\left|\gamma P J M_{J}\right\rangle=\sum_{j=1}^{\mathrm{NCSFs}} c_{j}\left|\gamma_{j} P J M_{J}\right\rangle
$$

In the expression above, $P, J$ and $M_{J}$ are the parity and the angular quantum numbers. $\gamma$ denotes other appropriate labelling of the CSF, for example, orbital occupancy, and coupling scheme. The CSFs are built from products of one-electron Dirac orbitals. In the relativistic self-consistent field (RSCF) procedure, both the radial parts of the Dirac orbitals and the expansion coefficients are optimized to selfconsistency. The Breit interaction

$$
\begin{aligned}
H_{\text {Breit }} & =-\sum_{i<j}^{N}\left[\boldsymbol{\alpha}_{i} \cdot \boldsymbol{\alpha}_{j} \frac{\cos \left(\omega_{i j} r_{i j} / c\right)}{r_{i j}}\right. \\
& \left.+\left(\boldsymbol{\alpha}_{i} \cdot \nabla_{i}\right)\left(\boldsymbol{\alpha}_{j} \cdot \nabla_{j}\right) \frac{\cos \left(\omega_{i j} r_{i j} / c\right)-1}{\omega_{i j}^{2} r_{i j} / c^{2}}\right]
\end{aligned}
$$

as well as leading quantum electrodynamic (QED) corrections can be included in subsequent relativistic configuration interaction (RCI) calculations [12]. Calculations can be performed for single levels, but also for portions of a spectrum in the extended optimal level (EOL) scheme, where optimization is on a weighted sum of energies [13]. Using the latter scheme, a balanced description of a number of fine-structure states belonging to one or more configurations can be obtained in a single calculation. All calculations were performed with a new release [7] of the GRASP2K code [8].

\section{Computation of atomic properties}

Once the ASFs have been obtained, measurable properties such as hyperfine structures, Landé $g_{J}$-factors and transition rates can be expressed in terms of reduced matrix elements of tensor operators of different rank,

$$
\left\langle\gamma P J\left\|\mathbf{T}^{(k)}\right\| \gamma^{\prime} P^{\prime} J^{\prime}\right\rangle
$$

Inserting the CSF expansions, the expression above reduces to a sum over matrix elements between CSFs. Using Racah algebra techniques, these matrix elements, in turn, can be obtained as sums over radial integrals [14].

\subsection{Hyperfine structure}

In atoms with non-zero nuclear spin, $I$, the fine-structure levels are split into closely spaced hyperfine levels. The splittings of the fine-structure levels are to first order given by the magnetic dipole, $A_{J}$, and electric quadrupole, $B_{J}$, hyperfine interaction constants,

$$
\begin{aligned}
A_{J}= & \frac{\mu_{I}}{I} \frac{1}{\sqrt{J(J+1)}}\left\langle\gamma P J \| \sum_{j=1}^{N}\right. \\
& \left.-\mathrm{i} \sqrt{2} \alpha r_{j}^{-2}\left(\boldsymbol{\alpha}_{j} \mathbf{C}^{(1)}(j)\right)^{(1)} \| \gamma P J\right\rangle,
\end{aligned}
$$

$$
B_{J}=2 Q \sqrt{\frac{J(2 J-1)}{(J+1)(2 J+3)}}\left\langle\gamma P J\left\|\sum_{j=1}^{N}-r_{j}^{-3} \mathbf{C}^{(2)}(j)\right\| \gamma P J\right\rangle,
$$

where the reduced matrix elements are defined in the Brink and Satchler sense $[15,16]$. The hyperfine levels of closely spaced fine-structure levels are also affected by the off-diagonal hyperfine interaction that mixes states with different $J$ values and opens forbidden decay channels such as $5 \mathrm{~s}^{2}{ }^{1} \mathrm{~S}_{0}-5 \mathrm{~s} 5 \mathrm{p}{ }^{3} \mathrm{P}_{0}^{\mathrm{o}}$, see for example [17-19]. The nuclear magnetic dipole moments, $\mu_{I}$, and the nuclear quadrupole moments, $Q$, for the different isotopes were taken from a compilation by Stone [20].

\subsection{Landé $g_{J}$-factors}

The Landé $g_{J}$-factors are given by

$$
\begin{aligned}
g_{J}= & \frac{2}{\sqrt{J(J+1)}}\left\langle\gamma P J \| \sum_{j=1}^{N}\right. \\
& \left.\times\left[-\mathrm{i} \frac{\sqrt{2}}{2 \alpha^{2}} r_{j}\left(\boldsymbol{\alpha}_{j} \mathbf{C}^{(1)}(j)\right)^{(1)}+\frac{g_{s}-2}{2} \beta_{j} \Sigma_{j}\right] \| \gamma P J\right\rangle,
\end{aligned}
$$

and determine the splitting of magnetic sub-levels in external magnetic fields. In addition, they give valuable information about the coupling conditions in the system [21]. The Landé $g_{J}$-factors were calculated using the Zeeman module of GRASP2K [22].

\subsection{Isotope shift}

Corrections to the calculated energy structure due to isotopedependent recoil motion of the nucleus and finite nuclear volume effects were included in first-order perturbation theory with the ASFs as zero-order functions. The corrections, within the lowest-order relativistic approximation $\left(v^{2} / c^{2}\right)$ and to first order in $m_{e} / M$, can be written $[23,24]$ as

$$
E_{M}=\left(S_{\mathrm{nms}}+S_{\mathrm{sms}}\right) \frac{1}{M}+\frac{2}{3} \pi Z \rho(0)\left\langle r_{M}^{2}\right\rangle,
$$

where

$$
\begin{aligned}
S_{\mathrm{nms}} & =\left\langle\gamma P J M_{J}\right| \frac{1}{2} \sum_{j=1}^{N}\left(\mathbf{p}_{j}^{2}-\frac{\alpha Z}{r_{j}} \boldsymbol{\alpha}_{j} \cdot \mathbf{p}_{j}\right. \\
& \left.-\frac{\alpha Z}{r_{j}}\left(\boldsymbol{\alpha}_{j} \cdot \mathbf{C}_{j}^{1}\right) \mathbf{C}_{j}^{1} \cdot \mathbf{p}_{j}\right)\left|\gamma P J M_{J}\right\rangle
\end{aligned}
$$

and

$$
\begin{aligned}
S_{\mathrm{sms}} & =\left\langle\gamma P J M_{J}\right| \frac{1}{2} \sum_{i \neq j}^{N}\left(\mathbf{p}_{i} \cdot \mathbf{p}_{j}-\frac{\alpha Z}{r_{i}} \boldsymbol{\alpha}_{i} \cdot \mathbf{p}_{j}\right. \\
& \left.-\frac{\alpha Z}{r_{i}}\left(\boldsymbol{\alpha}_{i} \cdot \mathbf{C}_{i}^{1}\right) \mathbf{C}_{i}^{1} \cdot \mathbf{p}_{j}\right)\left|\gamma P J M_{J}\right\rangle
\end{aligned}
$$

are, respectively, the normal and specific mass shift parameters. The expectation value

$$
\rho(0)=\left\langle\gamma P J M_{J}\left|\sum_{j=1}^{N} \delta\left(\mathbf{r}_{j}\right)\right| \gamma P J M_{J}\right\rangle
$$


gives the electron density at the site of the nucleus. $M$ is the mass of the nucleus and $\left\langle r_{M}^{2}\right\rangle$ is the root-mean-square radius, both in atomic units. From these quantities, the transition isotope shift $\Delta E_{M^{\prime}, M}$ between two isotopes $M^{\prime}$ and $M$ was obtained as

$$
\begin{gathered}
\Delta E_{M^{\prime}, M}=\left(\Delta S_{\mathrm{nms}}+\Delta S_{\mathrm{sms}}\right)\left(\frac{1}{M^{\prime}}-\frac{1}{M}\right) \\
+\frac{2 \pi}{3} Z \Delta \rho(0)\left(\left\langle r_{M^{\prime}}^{2}\right\rangle-\left\langle r_{M}^{2}\right\rangle\right),
\end{gathered}
$$

where the differences in the electronic quantities are between the values of upper and lower levels in the transition. The isotope shift parameters were calculated using a new isotope shift module RIS [25] of the GRASP2K package.

\subsection{Transition parameters}

The transition parameters, such as rates for spontaneous decay, for multipole transitions between two atomic states $\gamma P J M_{J}$ and $\gamma^{\prime} P^{\prime} J^{\prime} M_{J}^{\prime}$ can be expressed in terms of the reduced matrix elements,

$$
\left\langle\gamma P J\left\|\mathbf{Q}_{k}^{(\lambda)}\right\| \gamma^{\prime} P^{\prime} J^{\prime}\right\rangle
$$

where $\mathbf{Q}_{k}^{(\lambda)}$ is the electromagnetic multipole operator of order $k$ in length (Babushkin) or velocity (Coulomb) gauge [26]. The superscript designates the type of multipole: $\lambda=1$ for electric multipoles and $\lambda=0$ for magnetic multipoles. Standard Racah algebra assumes that the ASFs are built from the same orthogonal radial orbital set [14]. However, this restriction can be relaxed. To compute transition matrix elements between two ASFs described by independently optimized orbital sets, transformations of the ASFs are performed in such a way that the orbital sets become biorthogonal, in which case the calculation can be handled using standard techniques [27, 28].

\section{Calculations}

\subsection{Spectrum}

It is, from some perspectives, desirable to perform separate calculations for each of the studied fine-structure states. This approach, however, is impractical and time consuming when considering large portions of a spectrum. In this work, the ASFs were instead determined simultaneously in EOL calculations on the weighted energy average of the fine-structure states [13]. As a starting point, two MCDHF calculations were performed in the EOL scheme: one calculation with CSFs describing the 24 even-parity states from the $5 \mathrm{~s}^{2}{ }^{1} \mathrm{~S}_{0}$ ground state up to $5 \mathrm{~s} 8 \mathrm{~s}{ }^{1} \mathrm{~S}_{0}$, and one calculation with CSFs describing the 36 odd-parity states from $5 \mathrm{~s} 5 \mathrm{p}{ }^{3} \mathrm{P}_{0}^{\mathrm{o}}$ up to $5 \mathrm{p} 6 \mathrm{~s}{ }^{1} \mathrm{P}_{1}^{\mathrm{o}}$. To correct for electron correlation effects, these calculations were followed by calculations with expansions including CSFs obtained by single (S) and double (D) excitations from, respectively, the studied even- and odd-state reference configurations to active sets of orbitals. Of the excitations from the even- and odd-state reference configurations, at most one was allowed from the outer $4 \mathrm{~d}$ core shell. The $1 \mathrm{~s}, 2 \mathrm{~s}, \ldots, 4 \mathrm{~s}, 4 \mathrm{p}$ core shells are all kept closed. The active sets for the even- and odd-parity states, consisting of spectroscopic orbitals from the initial MCDHF calculations, were consecutively enlarged by adding four layers of correlation orbitals. Each layer contained orbitals with s, p, d, f, g symmetries (in non-relativistic notation). Two layers also included orbitals with h symmetry. Due to stability problems in the RSCF procedure, only the outermost layers of orbitals could be optimized each time. The largest calculation for the even-parity states included 66 relativistic orbitals and more than $217000 \mathrm{CSF}$ distributed over the $J=0,1,2,3,4,5$ symmetries. The largest calculation for the odd-parity states was based on 68 relativistic orbitals and around $373000 \mathrm{CSF}$ with symmetries $J=0,1,2,3,4$. The MCDHF calculations were complemented by final RCI calculations, where the Breit interaction was added to the electron-electron Coulomb interaction.

\subsection{Ground and first excited states}

In EOL calculations, the included correlation orbitals correct the wavefunctions for a number of fine-structure states at the same time. Obviously this will give less accurate results compared with the case where the correlation orbitals are obtained in separate calculations for each of the states. To check the accuracy of the spectrum calculations described above, separate calculations were performed for the $5 \mathrm{~s}^{2}{ }^{1} \mathrm{~S}_{0}$ ground state and the excited $5 \mathrm{~s} 5 \mathrm{p}{ }^{3} \mathrm{P}_{0,1,2}^{\mathrm{o}},{ }^{1} \mathrm{P}_{1}^{\mathrm{o}}$ states. The expansions for the ground state were obtained by allowing SD excitations from the $5 \mathrm{~s}^{2}, 5 \mathrm{p}^{2}$ and $5 \mathrm{~d}^{2}$ complex to an active set. As for the full spectrum calculations, at most one excitation was allowed from the outer $4 \mathrm{~d}$ core shell. The $5 \mathrm{~s} 5 \mathrm{p}^{3} \mathrm{P}_{0,1,2}^{\mathrm{o}},{ }^{1} \mathrm{P}_{1}^{\mathrm{o}}$ states were treated together in an EOL scheme. The expansions for these states were obtained by allowing SD excitations from the $5 \mathrm{~s} 5 \mathrm{p}$ and $5 \mathrm{p} 5 \mathrm{~d}$ complex to an active set. The active sets were increased by adding five layers of correlation orbitals. All calculations were followed by RCI calculations including the Breit interaction. To account for spin- and orbitalpolarization, additional RCI calculations were performed with the expansions from the previous RCI calculations augmented by CSFs generated by allowing single excitations from all core shells of the initial reference configurations to the active set of orbitals [29]. Although the radial orbitals are optimized on valence- and core-valence effects, and thus do not have the optimal location for accounting for spin-polarization effects, this approach has previously been shown to be quite successful [30].

\section{Results and discussion}

\subsection{Spectrum properties}

Energy values from the spectrum calculations are displayed in table 1 . The inclusion of the valence and core-valence correlation effects within the CSF basis, on which the four layers of correlation orbitals are optimized, improves the energies dramatically, and the final energies are in very good agreement with experiment with an average difference of only $0.12 \%$. The majority of the levels are a few hundred $\mathrm{cm}^{-1}$ too high relative to the $5 \mathrm{~s}^{2}{ }^{1} \mathrm{~S}_{0}$ ground level. The $5 \mathrm{p}^{2}{ }^{1} \mathrm{~S}_{0}$ and $5 \mathrm{p} 6 \mathrm{~s}{ }^{1} \mathrm{P}_{1}^{\mathrm{o}}$ levels are around $900 \mathrm{~cm}^{-1}$ too high, but they 
Table 1. Calculated and experimental energy levels in $\mathrm{cm}^{-1}$. Columns 2 and 3 present respectively the $L S$-compositions and Landé $g_{J}$-factors. Column 5 displays experimental energies and energies from HFR calculations by Rana et al [1]. The latter energies are denoted by $*$. The last column, labelled 'Diff', gives differences in energy between experiment and the largest calculation-based four layers of correlation orbitals. In some cases, the level designations do not agree with the ones given by Rana et al [1]. Whenever this is the case, the designation from the latter work is given in parentheses on the line below. Note that we have retained the designation $5 \mathrm{p} 5 \mathrm{~d}^{3} \mathrm{P}_{2}^{\mathrm{o}}$ suggested by Rana et al for the level at $265094.3 \mathrm{~cm}^{-1}$.

\begin{tabular}{|c|c|c|c|c|c|}
\hline Level & $L S$-composition & $g_{J}$ & $E$ & Exp/HFR & Diff \\
\hline $5 s^{2}{ }^{1} S_{0}$ & $0.955 \mathrm{~s}^{2}{ }^{1} \mathrm{~S}+0.025 \mathrm{p}^{2}{ }^{1} \mathrm{~S}$ & & & & \\
\hline $5 \mathrm{~s} 5 \mathrm{p}^{3} \mathrm{P}_{0}^{\mathrm{o}}$ & $0.985 \mathrm{~s} 5 \mathrm{p}^{3} \mathrm{P}^{\mathrm{o}}$ & & 64735 & 64437.3 & -298 \\
\hline $5 \mathrm{~s} 5 \mathrm{p}^{3} \mathrm{P}_{1}^{0}$ & $0.965 \mathrm{~s} 5 \mathrm{p}^{3} \mathrm{P}^{\mathrm{o}}$ & 1.493 & 66952 & 66698.1 & -255 \\
\hline $5 \mathrm{~s} 5 \mathrm{p}^{3} \mathrm{P}_{2}^{1}$ & $0.985 \mathrm{~s} 5 \mathrm{p}^{3} \mathrm{P}^{\mathrm{o}}$ & 1.501 & 72727 & 72555.7 & -172 \\
\hline $5 \mathrm{~s} 5 \mathrm{p}^{1} \mathrm{P}_{1}^{\mathrm{o}}$ & $0.935 \mathrm{~s} 5 \mathrm{p}^{1} \mathrm{P}^{\mathrm{o}}$ & 1.008 & 95551 & 95956.7 & 405 \\
\hline $5 \mathrm{p}^{23} \mathrm{P}_{0}$ & $0.935 \mathrm{p}^{2}{ }^{3} \mathrm{P}+0.045 \mathrm{p}^{2}{ }^{1} \mathrm{~S}$ & & 152137 & 152063.2 & -74 \\
\hline $5 \mathrm{p}^{2}{ }^{1} \mathrm{D}_{2}$ & $0.565 \mathrm{p}^{2}{ }^{1} \mathrm{D}+0.275 \mathrm{p}^{2}{ }^{3} \mathrm{P}+0.125 \mathrm{~s} 5 \mathrm{~d}^{1} \mathrm{D}$ & 1.140 & 156322 & 155947.6 & -375 \\
\hline $5 \mathrm{p}^{2}{ }^{3} \mathrm{P}_{1}$ & $0.975 \mathrm{p}^{2}{ }^{3} \mathrm{P}$ & 1.501 & 156339 & 156381.7 & 42 \\
\hline $5 \mathrm{p}^{2}{ }^{3} \mathrm{P}_{2}$ & $0.705 p^{2}{ }^{3} \mathrm{P}+0.195 \mathrm{p}^{2}{ }^{1} \mathrm{D}+0.075 \mathrm{~s} 5 \mathrm{~d}^{1} \mathrm{D}$ & 1.359 & 163548 & 163521.4 & -27 \\
\hline $5 \mathrm{~s} 5 \mathrm{~d}^{3} \mathrm{D}_{1}$ & $0.825 \mathrm{~s} 5 \mathrm{~d}^{3} \mathrm{D}+0.155 \mathrm{~s} 6 \mathrm{~d}^{3} \mathrm{D}$ & 0.499 & 178895 & 178913.3 & 18 \\
\hline $5 \mathrm{~s} 5 \mathrm{~d}^{3} \mathrm{D}_{2}$ & $0.825 \mathrm{~s} 5 \mathrm{~d}^{3} \mathrm{D}+0.155 \mathrm{~s} 6 \mathrm{~d}^{3} \mathrm{D}$ & 1.167 & 179244 & 179264.7 & 20 \\
\hline $55 d^{3} D_{3}$ & $0.835 \mathrm{~s} 5 \mathrm{~d}^{3} \mathrm{D}+0.145 \mathrm{~s} 6 \mathrm{~d}^{3} \mathrm{D}$ & 1.334 & 179877 & 179820.9 & -57 \\
\hline $5 \mathrm{p}^{2}{ }^{1} \mathrm{~S}_{0}$ & $0.875 p^{2}{ }^{1} \mathrm{~S}+0.045 \mathrm{p}^{2}{ }^{3} \mathrm{P}$ & & 185345 & 184429.5 & -916 \\
\hline $5 \mathrm{~s} 6 \mathrm{~s}{ }^{3} \mathrm{~S}_{1}$ & $0.845 \mathrm{~s} 6 \mathrm{~s}{ }^{3} \mathrm{~S}+0.085 \mathrm{~s} 7 \mathrm{~s}{ }^{3} \mathrm{~S}+0$ & 2.002 & 188837 & 188623.0 & -214 \\
\hline $5 \mathrm{~s} 5 \mathrm{~d}^{1} \mathrm{D}_{2}$ & $0.675 \mathrm{~s} 5 \mathrm{~d}^{1} \mathrm{D}+0.215 \mathrm{p}^{2}{ }^{1} \mathrm{D}+0.0$ & 1.002 & 193679 & 193445.6 & -234 \\
\hline $5 \mathrm{~s} 6 \mathrm{~s}{ }^{1} \mathrm{~S}_{0}$ & $0.855 \mathrm{~s} 6 \mathrm{~s}{ }^{1} \mathrm{~S}+0.065 \mathrm{~s} 7 \mathrm{~s}{ }^{1} \mathrm{~S}$ & & 194313 & 193948.4 & -365 \\
\hline $5 \mathrm{~s} 6 \mathrm{p}^{3} \mathrm{P}_{0}^{\mathrm{o}}$ & $0.875 \mathrm{~s} 6 \mathrm{p}^{3} \mathrm{P}^{\mathrm{o}}+0.105 \mathrm{~s} 7 \mathrm{p}^{3} \mathrm{P}^{\mathrm{o}}$ & & 215581 & 215387.3 & -194 \\
\hline $5 \mathrm{~s} 6 \mathrm{p}^{3} \mathrm{P}_{1}^{\mathrm{o}}$ & $0.765 \mathrm{~s} 6 \mathrm{p}^{3} \mathrm{P}^{\mathrm{o}}+0.125 \mathrm{~s} 6 \mathrm{p}^{1} \mathrm{P}^{\mathrm{o}}+0.085 \mathrm{~s} 7 \mathrm{p}^{3} \mathrm{P}^{\mathrm{o}}$ & 1.433 & 215922 & 215734.1 & -189 \\
\hline $5 \mathrm{~s} 6 \mathrm{p}^{3} \mathrm{P}_{2}^{\mathrm{o}}$ & $0.875 \mathrm{~s} 6 \mathrm{p}^{3} \mathrm{P}^{\mathrm{o}}+0.105 \mathrm{~s} 7 \mathrm{p}^{3} \mathrm{P}^{\mathrm{o}}$ & 1.501 & 217960 & 217804.8 & -156 \\
\hline $5 \mathrm{~s} 6 \mathrm{p}^{1} \mathrm{P}_{1}^{\mathrm{o}}$ & $0.755 \mathrm{~s} 6 \mathrm{p}^{1} \mathrm{P}^{\mathrm{o}}+0.125 \mathrm{~s} 6 \mathrm{p}^{3} \mathrm{P}^{\mathrm{o}}+0.075 \mathrm{~s} 7 \mathrm{p}^{1} \mathrm{P}^{\mathrm{o}}$ & 1.068 & 219187 & 219029.0 & -158 \\
\hline $5 \mathrm{~s} 4 \mathrm{f}^{3} \mathrm{~F}_{2}^{\mathrm{o}}$ & $0.585 \mathrm{~s} 4 \mathrm{f}^{3} \mathrm{~F}^{\mathrm{o}}+0.355 \mathrm{~s} 5 \mathrm{f}^{3} \mathrm{~F}^{\mathrm{o}}+0.055 \mathrm{p} 5 \mathrm{~d}^{3} \mathrm{~F}^{\mathrm{o}}$ & 0.666 & 227203 & 227059.0 & -144 \\
\hline $5 \mathrm{~s} 4 \mathrm{f}^{3} \mathrm{~F}_{3}^{\mathrm{o}}$ & $0.585 \mathrm{~s} 4 \mathrm{f}^{3} \mathrm{~F}^{\mathrm{o}}+0.335 \mathrm{~s} 5 \mathrm{f}^{3} \mathrm{~F}^{\mathrm{o}}+0.045 \mathrm{p} 5 \mathrm{~d}^{3} \mathrm{~F}^{\mathrm{o}}$ & 1.081 & 227264 & 227144.0 & -120 \\
\hline $5 \mathrm{~s} 4 \mathrm{f}^{3} \mathrm{~F}_{4}^{\mathrm{o}}$ & $0.625 \mathrm{~s} 4 \mathrm{f}^{3} \mathrm{~F}^{\mathrm{o}}+0.335 \mathrm{~s} 5 \mathrm{f}^{3} \mathrm{~F}^{\mathrm{o}}+0.035 \mathrm{p} 5 \mathrm{~d}^{3} \mathrm{~F}^{\mathrm{o}}$ & 1.250 & 227420 & 227304.0 & -116 \\
\hline $5 \mathrm{~s} 4 \mathrm{f}^{1} \mathrm{~F}_{3}^{\mathrm{o}}$ & $0.585 \mathrm{~s} 4 \mathrm{f}^{1} \mathrm{~F}^{\mathrm{o}}+0.305 \mathrm{~s} 5 \mathrm{f}^{1} \mathrm{~F}^{\mathrm{o}}+0.075 \mathrm{p} 5 \mathrm{~d}^{1} \mathrm{~F}^{\mathrm{o}}$ & 1.002 & 228499 & 228438.0 & -61 \\
\hline $5 \mathrm{p} 5 \mathrm{~d}^{3} \mathrm{~F}_{2}^{\mathrm{o}}$ & $0.665 \mathrm{p} 5 \mathrm{~d}^{3} \mathrm{~F}^{\mathrm{o}}+0.265 \mathrm{p} 5 \mathrm{~d}^{1} \mathrm{D}^{\mathrm{o}}+0.035 \mathrm{~s} 4 \mathrm{f}^{3} \mathrm{~F}^{\mathrm{o}}$ & 0.764 & 254321 & 254143.8 & -178 \\
\hline $5 \mathrm{~s} 6 \mathrm{~d}^{3} \mathrm{D}_{1}$ & $0.825 \mathrm{~s} 6 \mathrm{~d}^{3} \mathrm{D}+0.155 \mathrm{~s} 5 \mathrm{~d}^{3} \mathrm{D}$ & 0.499 & 254958 & 254678.4 & -280 \\
\hline $5 \mathrm{~s} 6 \mathrm{~d}^{3} \mathrm{D}_{2}$ & $0.825 \mathrm{~s} 6 \mathrm{~d}^{3} \mathrm{D}+0.155 \mathrm{~s} 5 \mathrm{~d}^{3} \mathrm{D}$ & 1.166 & 255094 & 254829.0 & -265 \\
\hline $5 \mathrm{~s} 6 \mathrm{~d}^{3} \mathrm{D}_{3}$ & $0.835 \mathrm{~s} 6 \mathrm{~d}^{3} \mathrm{D}+0.145 \mathrm{~s} 5 \mathrm{~d}^{3} \mathrm{D}$ & 1.334 & 255373 & 255081.6 & -292 \\
\hline $5 \mathrm{~s} 6 \mathrm{~d}^{1} \mathrm{D}_{2}$ & $0.845 \mathrm{~s} 6 \mathrm{~d}^{1} \mathrm{D}+0.145 \mathrm{~s} 5 \mathrm{~d}^{1} \mathrm{D}$ & 1.001 & & 13.6 & -421 \\
\hline $5 \mathrm{~s} 7 \mathrm{~s}{ }^{3} \mathrm{~S}_{1}$ & $0.665 \mathrm{~s} 7 \mathrm{~s}{ }^{3} \mathrm{~S}+0.195 \mathrm{~s} 8 \mathrm{~s}{ }^{3} \mathrm{~S}+0.135 \mathrm{~s} 6 \mathrm{~s}{ }^{3} \mathrm{~S}$ & 2.002 & 258061 & 257771.9 & -290 \\
\hline $5 \mathrm{p} 5 \mathrm{~d}^{3} \mathrm{~F}_{3}^{\mathrm{o}}$ & $0.855 \mathrm{p} 5 \mathrm{~d}^{3} \mathrm{~F}^{\mathrm{o}}+0.065 \mathrm{p} 5 \mathrm{~d}^{3} \mathrm{D}^{\mathrm{o}}+0.044 \mathrm{f} 5 \mathrm{~s}^{3} \mathrm{~F}^{\mathrm{o}}$ & 1.098 & 258051 & 257840.1 & -212 \\
\hline $5 \mathrm{p} 5 \mathrm{~d}^{1} \mathrm{D}_{2}^{\mathrm{o}}$ & $0.515 \mathrm{p} 5 \mathrm{~d}^{1} \mathrm{D}^{\mathrm{o}}+0.185 \mathrm{p} 5 \mathrm{~d}^{3} \mathrm{~F}^{\mathrm{o}}+0.155 \mathrm{p} 5 \mathrm{~d}^{3} \mathrm{P}^{\mathrm{o}}$ & 1.035 & 258962 & 258835.2 & -127 \\
\hline $5 \mathrm{~s} 7 \mathrm{~s}{ }^{1} \mathrm{~S}_{0}{ }^{2}$ & $0.705 \mathrm{~s} 7 \mathrm{~s}{ }^{1} \mathrm{~S}+0.175 \mathrm{~s} 8 \mathrm{~s}{ }^{1} \mathrm{~S}+0.115 \mathrm{~s} 6 \mathrm{~s}^{1} \mathrm{~S}$ & & 259666 & 259327.3 & -339 \\
\hline $5 \mathrm{p} 5 \mathrm{~d}^{3} \mathrm{~F}_{4}^{\mathrm{o}}$ & $0.935 \mathrm{p} 5 \mathrm{~d}^{3} \mathrm{~F}^{\mathrm{o}}+0.045 \mathrm{~s} 4 \mathrm{f}^{3} \mathrm{~F}^{\mathrm{o}}$ & 1.250 & 262878 & 262631.5 & -247 \\
\hline $5 \mathrm{p} 5 \mathrm{~d}^{3} \mathrm{D}_{1}^{\mathrm{o}}$ & $0.725 \mathrm{p} 5 \mathrm{~d}^{3} \mathrm{D}^{\mathrm{o}}+0.185 \mathrm{p} 5 \mathrm{~d}^{3} \mathrm{P}^{\mathrm{o}}+0.055 \mathrm{p} 5 \mathrm{~d}^{1} \mathrm{P}^{\mathrm{o}}$ & 0.729 & 262971 & 262962.2 & -10 \\
\hline $5 \mathrm{p} 5 \mathrm{~d}^{3} \mathrm{P}_{2}^{\mathrm{o}}$ & $0.285 \mathrm{p} 5 \mathrm{~d}^{3} \mathrm{P}^{\mathrm{o}}+0.405 \mathrm{p} 5 \mathrm{~d}^{3} \mathrm{D}^{\mathrm{o}}+0.205 \mathrm{p} 5 \mathrm{~d}^{1} \mathrm{D}^{\mathrm{o}}$ & 1.198 & 265146 & 265094.3 & -52 \\
\hline $5 \mathrm{p} 5 \mathrm{~d}^{3} \mathrm{P}_{0}^{\mathrm{o}}$ & $0.455 \mathrm{p} 5 \mathrm{~d}^{3} \mathrm{P}^{\mathrm{o}}+0.445 \mathrm{~s} 7 \mathrm{p}^{3} \mathrm{P}^{\mathrm{o}}+0.085 \mathrm{~s} 6 \mathrm{p}^{3} \mathrm{P}^{\mathrm{o}}$ & & 268390 & 268108.0 & -282 \\
\hline $\begin{array}{l}5 \mathrm{p} 5 \mathrm{~d}^{3} \mathrm{P}_{1}^{\mathrm{o}} \\
\left(5 \mathrm{~s} 7 \mathrm{p}{ }^{1} \mathrm{P}_{1}^{\mathrm{o}}\right)\end{array}$ & $\begin{array}{l}0.365 \mathrm{p} 5 \mathrm{~d}^{3} \mathrm{P}^{\mathrm{o}}+0.315 \mathrm{~s} 7 \mathrm{p}^{3} \mathrm{P}^{\mathrm{o}}+0.135 \mathrm{p} 5 \mathrm{~d}^{3} \mathrm{D}^{\mathrm{o}} \\
\left(0.285 \mathrm{~s} 7 \mathrm{p}^{1} \mathrm{P}^{\mathrm{o}}+0.265 \mathrm{p} 5 \mathrm{~d}^{3} \mathrm{P}^{\mathrm{o}}+0.195 \mathrm{p} 6 \mathrm{~s}^{3} \mathrm{P}^{\mathrm{o}}\right)\end{array}$ & 1.306 & 268675 & 268471.2 & -204 \\
\hline $5 \mathrm{p} 5 \mathrm{~d}^{3} \mathrm{D}_{3}^{\mathrm{o}}$ & $0.855 \mathrm{p} 5 \mathrm{~d}^{3} \mathrm{D}^{\mathrm{o}}+0.075 \mathrm{p} 5 \mathrm{~d}^{3} \mathrm{~F}^{\mathrm{o}}$ & 1.299 & 268407 & 268547.5 & 140 \\
\hline $\begin{array}{l}5 \mathrm{p} 6 \mathrm{~s}^{3} \mathrm{P}_{0}^{\mathrm{o}} \\
\left(5 \mathrm{~s} 7 \mathrm{p}^{3} \mathrm{P}_{0}^{\mathrm{o}}\right)\end{array}$ & $\begin{array}{l}0.605 \mathrm{p} 6 \mathrm{~s}^{3} \mathrm{P}^{\mathrm{o}}+0.265 \mathrm{p} 5 \mathrm{~d}^{3} \mathrm{P}^{\mathrm{o}}+0.115 \mathrm{~s} 7 \mathrm{p}^{3} \mathrm{P}^{\mathrm{o}} \\
\left(0.585 \mathrm{~s} 7 \mathrm{p}^{3} \mathrm{P}^{\mathrm{o}}+0.415 \mathrm{p} 6 \mathrm{~s}^{3} \mathrm{P}^{\mathrm{o}}\right)\end{array}$ & & 270527 & $269052^{*}$ & -1475 \\
\hline $\begin{array}{l}5 \mathrm{~s} 7 \mathrm{p}^{1} \mathrm{P}_{1}^{\mathrm{o}} \\
\left(5 \mathrm{~s} 7 \mathrm{p}^{3} \mathrm{P}_{1}^{\mathrm{o}}\right)\end{array}$ & $\begin{array}{l}0.405 \mathrm{~s} 7 \mathrm{p}^{1}{ }^{\mathrm{o}}+0.215 \mathrm{p} 6 \mathrm{~s}^{1} \mathrm{P}^{\mathrm{o}}+0.165 \mathrm{p} 6 \mathrm{~s}^{3} \mathrm{P}^{\mathrm{o}} \\
\left(0.285 \mathrm{~s} 7 \mathrm{p}^{3} \mathrm{P}^{\mathrm{o}}+0.255 \mathrm{p} 5 \mathrm{~d}^{3} \mathrm{P}^{\mathrm{o}}+0.165 \mathrm{~s} 7 \mathrm{p}^{1} \mathrm{P}^{\mathrm{o}}\right)\end{array}$ & 1.111 & 269160 & $269078^{*}$ & -82 \\
\hline $5 \mathrm{p} 5 \mathrm{~d}^{3} \mathrm{D}_{2}^{\mathrm{o}}$ & $0.395 \mathrm{p} 5 \mathrm{~d}^{3} \mathrm{D}^{\mathrm{o}}+0.345 \mathrm{p} 5 \mathrm{~d}^{3} \mathrm{P}^{\mathrm{o}}+0.195 \mathrm{~s} 7 \mathrm{p}^{3} \mathrm{P}^{\mathrm{o}}$ & 1.356 & 269232 & 95.4 & -37 \\
\hline $5 \mathrm{~s} 7 \mathrm{p}^{3} \mathrm{P}_{1}^{\mathrm{o}}$ & $0.335 \mathrm{~s} 7 \mathrm{p}^{3} \mathrm{P}^{\mathrm{o}}+0.325 \mathrm{p} 5 \mathrm{~d}^{3} \mathrm{P}^{\mathrm{o}}+0.165 \mathrm{p} 6 \mathrm{~s}^{3} \mathrm{P}^{\mathrm{o}}$ & 1.407 & 271320 & $270319^{*}$ & -1002 \\
\hline $5 \mathrm{~s} 5 \mathrm{f}^{1} \mathrm{~F}_{3}^{\mathrm{o}}$ & $0.465 \mathrm{~s} 5 \mathrm{f}^{1} \mathrm{~F}^{\mathrm{o}}+0.365 \mathrm{~s} 4 \mathrm{f}^{1} \mathrm{~F}^{\mathrm{o}}+0.115 \mathrm{p} 5 \mathrm{~d}^{1} \mathrm{~F}^{\mathrm{o}}$ & 1.015 & 271941 & $270947^{*}$ & -994 \\
\hline $5 s 7 p^{3} \mathrm{P}_{2}^{3}$ & $0.655 \mathrm{~s} 7 \mathrm{p}^{3} \mathrm{P}^{\mathrm{o}}+0.185 \mathrm{p} 5 \mathrm{~d}^{3} \mathrm{P}^{\mathrm{o}}+0.065 \mathrm{~s} 6 \mathrm{p}^{3} \mathrm{P}^{\mathrm{o}}$ & 1.481 & 271995 & $271375^{*}$ & -620 \\
\hline $5 \mathrm{~s} 5 \mathrm{f}^{3} \mathrm{~F}_{2}^{\mathrm{o}}$ & $0.605 \mathrm{~s} 5 \mathrm{f}^{3} \mathrm{~F}^{\mathrm{o}}+0.365 \mathrm{~s} 4 \mathrm{f}^{3} \mathrm{~F}^{\mathrm{o}}$ & 0.667 & 272673 & $272126^{*}$ & -547 \\
\hline $5 s 5 f^{3} \mathrm{~F}_{3}^{2}$ & $0.615 \mathrm{~s} 5 \mathrm{f}^{3} \mathrm{~F}^{\mathrm{o}}+0.345 \mathrm{~s} 4 \mathrm{f}^{3} \mathrm{~F}^{\mathrm{o}}$ & 1.084 & 272664 & $272175^{*}$ & -490 \\
\hline $5 s 5 f^{3} F_{4}^{o}$ & $0.635 \mathrm{~s} 5 \mathrm{f}^{3} \mathrm{~F}^{\mathrm{o}}+0.335 \mathrm{~s} 4 \mathrm{f}^{3} \mathrm{~F}^{\mathrm{o}}$ & 1.251 & 272695 & $272262^{*}$ & -434 \\
\hline $\begin{array}{l}5 \mathrm{~s} 7 \mathrm{p}^{3} \mathrm{P}_{0}^{\mathrm{o}} \\
\left(5 \mathrm{p} 6 \mathrm{~s}^{3} \mathrm{P}_{0}^{0}\right)\end{array}$ & $\begin{array}{l}0.345 \mathrm{~s} 7 \mathrm{p}^{3} \mathrm{P}^{\mathrm{o}}+0.365 \mathrm{p} 6 \mathrm{~s}^{3} \mathrm{P}^{\mathrm{o}}+0.265 \mathrm{p} 5 \mathrm{~d}^{3} \mathrm{P}^{\mathrm{o}} \\
\left(0.385 \mathrm{p} 6 \mathrm{~s}^{3} \mathrm{P}^{\mathrm{o}}+0.335 \mathrm{~s} 7 \mathrm{p}^{3} \mathrm{P}^{\mathrm{o}}+0.2855 \mathrm{p} 5 \mathrm{~d}^{3} \mathrm{P}^{\mathrm{o}}\right)\end{array}$ & & 272917 & 272690.0 & -227 \\
\hline 5 p6s ${ }^{3} \mathrm{P}_{1}^{\mathrm{o}}$ & $0.415 \mathrm{p} 6 \mathrm{~s}^{3} \mathrm{P}^{\mathrm{o}}+0.225 \mathrm{~s} 7 \mathrm{p}^{1} \mathrm{P}^{\mathrm{o}}+0.185 \mathrm{~s} 7 \mathrm{p}^{3} \mathrm{P}^{\mathrm{o}}$ & 1. & 78 & 2 & -244 \\
\hline $5 \mathrm{p} 5 \mathrm{~d}^{1} \mathrm{P}_{1}^{\mathrm{o}}$ & $0.455 \mathrm{p} 5 \mathrm{~d}^{1} \mathrm{P}^{\mathrm{o}}+0.225 \mathrm{p} 6 \mathrm{~s}{ }^{1} \mathrm{P}^{\mathrm{o}}+0.195 \mathrm{p} 6 \mathrm{~s}{ }^{3} \mathrm{P}^{\mathrm{o}}$ & 1.102 & 278635 & 278272.5 & -363 \\
\hline $5 \mathrm{p} 6 \mathrm{~s}^{3} \mathrm{P}_{2}^{\mathrm{o}}$ & $0.955 \mathrm{p} 6 \mathrm{~s}^{3} \mathrm{P}^{\mathrm{o}}+0.025 \mathrm{~s} 7 \mathrm{p}^{3} \mathrm{P}^{\mathrm{o}}$ & 1.501 & 279949 & 279778.0 & -172 \\
\hline $5 \mathrm{~s} 5 \mathrm{~g}^{1} \mathrm{G}_{4}$ & $0.505 \mathrm{~s} 5 \mathrm{~g}^{1} \mathrm{G}+0.485 \mathrm{~s} 5 \mathrm{~g}^{3} \mathrm{G}$ & 1.025 & 281639 & & \\
\hline $5 \mathrm{~s} 5 \mathrm{~g}^{3} \mathrm{G}_{3}$ & $0.985 \mathrm{~s} 5 \mathrm{~g}{ }^{3} \mathrm{G}$ & 0.749 & 281640 & & \\
\hline
\end{tabular}


Table 1. (Continued.)

\begin{tabular}{llllll}
\hline Level & $L S$-composition & $g_{J}$ & $E$ & Exp/HFR & Diff \\
\hline $5 \mathrm{~s} 5 \mathrm{~g}{ }^{3} \mathrm{G}_{4}$ & $0.505 \mathrm{~s} 5 \mathrm{~g}{ }^{3} \mathrm{G}+0.485 \mathrm{~s} 5 \mathrm{~g}{ }^{1} \mathrm{G}$ & 1.025 & 281688 & & \\
$5 \mathrm{~s} 5 \mathrm{~g}{ }^{3} \mathrm{G}_{5}$ & $0.985 \mathrm{~s} 5 \mathrm{~g}{ }^{3} \mathrm{G}$ & 1.200 & 281690 & & \\
$5 \mathrm{p} 5 \mathrm{~d}{ }^{1} \mathrm{~F}_{3}^{\mathrm{o}}$ & $0.735 \mathrm{p} 5 \mathrm{~d}{ }^{1} \mathrm{~F}^{\mathrm{o}}+0.195 \mathrm{~s} 5 \mathrm{f}{ }^{1} \mathrm{~F}^{\mathrm{o}}$ & 1.005 & 285989 & 285536.4 & -453 \\
$5 \mathrm{p} 6 \mathrm{~s}{ }^{1} \mathrm{P}_{1}^{\mathrm{o}}$ & $0.445 \mathrm{p} 6 \mathrm{~s}{ }^{1} \mathrm{P}^{\mathrm{o}}+0.395 \mathrm{p} 5 \mathrm{~d}{ }^{1} \mathrm{P}^{\mathrm{o}}+0.055 \mathrm{~s} 7 \mathrm{p}{ }^{1} \mathrm{P}^{\mathrm{o}}$ & 1.020 & 287180 & 286257.7 & -922 \\
$5 \mathrm{~s} 8 \mathrm{~s}{ }^{3} \mathrm{~S}_{1}$ & $0.745 \mathrm{~s} 8 \mathrm{~s}{ }^{3} \mathrm{~S}+0.245 \mathrm{~s} 7 \mathrm{~s}{ }^{3} \mathrm{~S}$ & 2.002 & 290771 & 290488.5 & -283 \\
$5 \mathrm{~s} 8 \mathrm{~s}{ }^{1} \mathrm{~S}_{0}$ & $0.775 \mathrm{~s} 8 \mathrm{~s}{ }^{1} \mathrm{~S}+0.215 \mathrm{~s} 7 \mathrm{~s}{ }^{1} \mathrm{~S}$ & & 291447 & 291405.8 & -41 \\
\hline
\end{tabular}

seem to be moving in the right direction as the orbital set is increased. Included in the comparison in table 1, there are eight predicted energy levels, denoted by asterisks, from the semiempirical multiconfiguration Hartree-Fock calculation with relativistic corrections (HFR) by Rana et al [1]. The agreement with the HFR values is not as good as with experiment, reaching $1500 \mathrm{~cm}^{-1}$ for the $5 \mathrm{p} 6 \mathrm{~s}^{3} \mathrm{P}_{0}^{\mathrm{o}}$ state (this state is labelled $5 \mathrm{~s} 7 \mathrm{p}^{3} \mathrm{P}_{0}^{\mathrm{o}}$ in the HFR calculations). These differences reflect the combined uncertainty of the two calculations. The labels for some of the levels are not consistent with the ones given by Rana, and in these cases, the corresponding label from the latter work is given in parentheses on the line below.

In relativistic calculations, the states are normally given in $j j$-coupling. To obtain more appropriate labels, we have performed a transformation to the $L S J$ coupling scheme. The transformation procedure was developed by Gaigalas and coworkers $[9,10]$ and adapted for large-scale calculations in the new release of the GRASP2K code [7]. In table 1, we give $L S$-compositions of the even and odd states. We also give the Landé $g_{J}$-factors, which provide information about the splittings of magnetic sub-levels in external magnetic fields. The 5p5d, 5s7p and 5p6s odd configurations overlap, with average energies of 266210,271183 and $276773 \mathrm{~cm}^{-1}$, respectively, and there is considerable configuration mixing for several states, making it difficult to assign a proper label. In the analysis by Rana et al, the positions of the levels of the $5 \mathrm{~s} 7 \mathrm{p}$ configuration could not be experimentally established and they had to guess the average energy in the HFR calculation. As commented by Rana et al, a slight shift in the average position of $5 \mathrm{~s} 7 \mathrm{p}$ has a dramatic effect on the $L S$-composition. Traces of this problem can be seen for the $5 \mathrm{p} 5 \mathrm{~d}^{3} \mathrm{P}_{1}^{\mathrm{o}}, 5 \mathrm{p} 6 \mathrm{~s}{ }^{3} \mathrm{P}_{0}^{\mathrm{o}}, 5 \mathrm{~s} 7 \mathrm{p}{ }^{1} \mathrm{P}_{1}^{\mathrm{o}}$, $5 \mathrm{~s} 7 \mathrm{p}{ }^{3} \mathrm{P}_{0}^{\mathrm{o}}$ states. Here the current $L S$-composition does not match the one from the HFR calculation. The composition from the latter calculation is given in parentheses on the line below. In addition, although not as severe, there is also an inconsistency in the labelling of the $5 \mathrm{p} 5 \mathrm{~d}^{3} \mathrm{D}_{2}^{\mathrm{o}}$ state. One should keep in mind that the labelling is not anything absolute, but in some cases with close degeneracies dependent on the calculation and the correlation effects included.

Table 2 gives the calculated lifetimes for all the states, where the length gauge has been used for the electric dipole transitions. The longest lifetimes are the ones of the $5 \mathrm{~s} 5 \mathrm{p}^{3} \mathrm{P}^{\mathrm{o}}$ term. In table 2, averaged calculated lifetimes of states belonging to nine terms (value in parentheses) are compared with values from cascade-corrected beam-foil measurements by Pinnington et al [2] and from other theory. The agreement between the current averaged lifetimes and experimental lifetimes is very good. The only exceptions are the $5 \mathrm{~s} 4 \mathrm{f}^{1,3} \mathrm{~F}^{\mathrm{o}}$ terms, where theory gives shorter lifetimes. We note that the Coulomb approximation gives unreliable values of the lifetimes [2].

Weighted oscillator strengths and transition rates for spontaneous emission are presented in table 3. Rates are based on computed transition energies. Length gauge has been used for the transitions. To assess the accuracy of the computed values, also the ratios, $R$, between the rates in the length and velocity gauges are given. In most cases, the ratio is close to 1 , but for some of the weaker transitions, values in the two gauges differ substantially, giving ratios far from 1 . The weakness of a transition frequently comes out as a result of cancellation between a number of large contributions or between different parts of the radial transition integrals [31]. A small imbalance due to correlation effects may thus change the calculated transition probabilities dramatically in one of the gauges. It is difficult to infer the accuracy of the computed transition parameters, but weak transitions with values of $R$ far from 1 are associated with rather large uncertainties.

One may note that there are several strong transitions between states belonging to configurations differing by more than one electron. One example is the $5 \mathrm{~s} 7 \mathrm{p}{ }^{1} \mathrm{P}_{1}^{\mathrm{o}}-5 \mathrm{p}^{2}{ }^{1} \mathrm{D}_{2}$ transition with the rate $1.19 \times 10^{9} \mathrm{~s}^{-1}$. These transition rates are identically zero in the independent particle model, and become allowed only due to configuration interaction effects [29].

\subsection{The resonance transition}

In table 4, energies and rates in length and velocity gauges for the $5 \mathrm{~s}^{2}{ }^{1} \mathrm{~S}_{0}-5 \mathrm{~s} 5 \mathrm{p}{ }^{3} \mathrm{P}_{1}^{\mathrm{o}}$ and $5 \mathrm{~s}^{2}{ }^{1} \mathrm{~S}_{0}-5 \mathrm{~s} 5 \mathrm{p}{ }^{1} \mathrm{P}_{1}^{\mathrm{o}}$ electric dipole (E1) transitions are shown. In addition, values are given for the weak $5 \mathrm{~s}^{2}{ }^{1} \mathrm{~S}_{0}-5 \mathrm{~s} 5 \mathrm{p}{ }^{3} \mathrm{P}_{2}^{\mathrm{o}}$ magnetic quadrupole (M2) transition. The values were obtained from increasingly large RCI calculations including the Breit interaction and leading QED effects. The transition parameters converge rapidly with the active sets, and basically only two layers of correlation orbitals are needed. Comparing the transition energies and rates with the ones from the spectrum calculation, we see that there is a very good consistency. The good overall agreement strengthens our confidence in the spectrum calculations, indicating that these include the same correlation effects as do the calculations targeted for the individual states. In table 4, values from the HFR and MCDHF calculations of Biémont et al [6] are also presented. The MCDHF calculations include the same correlation effects as the present calculations, but the ${ }^{1} \mathrm{P}_{1}^{\mathrm{o}}$ state is separately optimized in one calculation and the three ${ }^{3} \mathrm{P}^{\mathrm{o}}$ states in another. One notes the large effect of the optimization scheme on the rate of the allowed transition in 
Table 2. Lifetimes in ns. $\tau_{\mathrm{RCI}}$ : this work; $\tau_{\mathrm{exp}}$ : beam foil; $\tau_{C}$ :

Coulomb approximation; $\tau_{\mathrm{HFR}}$ : Hartree-Fock calculation including configuration interaction. The calculated lifetimes in the Coulomb approximation and using the HFR approximation are quoted from the paper by Pinnington et al [2]. When the level designation does not agree with the one given by Rana et al [1], the designation from the latter work is given in parentheses.

\begin{tabular}{|c|c|c|c|c|}
\hline State & $\tau_{\mathrm{RCI}}$ & $\tau_{\exp }^{\mathrm{a}}$ & $\tau_{C}^{\mathrm{a}}$ & $\tau_{\mathrm{HFR}}^{\mathrm{a}}$ \\
\hline $5 s 5 p^{3} P_{1}^{o}$ & 66.73 & & & \\
\hline $5 \mathrm{~s} 5 \mathrm{p}^{1} \mathrm{P}_{1}^{\mathrm{o}}$ & 0.32 & $0.38 \pm 0.04$ & 0.23 & 0.20 \\
\hline $5 \mathrm{p}^{2}{ }^{3} \mathrm{P}_{0}$ & 0.41 & & & \\
\hline $5 p^{2}{ }^{1} D_{2}$ & 1.15 & $1.40 \pm 0.25$ & 0.52 & 1.23 \\
\hline $5 p^{2}{ }^{3} \mathrm{P}_{1}$ & 0.38 & & & \\
\hline $5 p^{2}{ }^{3} \mathrm{P}_{2}$ & 0.46 & & & \\
\hline $5 \mathrm{~s} 5 \mathrm{~d}^{3} \mathrm{D}_{1}$ & $0.21(0.22)^{\mathrm{a}}$ & $0.25 \pm 0.05$ & 0.21 & 0.18 \\
\hline $5 s 5 d^{3} D_{2}$ & $0.21(0.22)^{\mathrm{a}}$ & $0.25 \pm 0.05$ & 0.21 & 0.18 \\
\hline $5 \mathrm{~s} 5 \mathrm{~d}^{3} \mathrm{D}_{3}$ & $0.23(0.22)^{\mathrm{a}}$ & $0.25 \pm 0.05$ & 0.21 & 0.18 \\
\hline $5 p^{2}{ }^{1} S_{0}$ & 0.46 & & & \\
\hline $5 \mathrm{~s} 6 \mathrm{~s}{ }^{3} \mathrm{~S}_{1}$ & 0.21 & & & \\
\hline $5 \mathrm{~s} 5 \mathrm{~d}^{1} \mathrm{D}_{2}$ & 0.16 & $0.19 \pm 0.04$ & 0.35 & 0.12 \\
\hline $5 \mathrm{~s} 6 \mathrm{~s}{ }^{1} \mathrm{~S}_{0}$ & 0.22 & & & \\
\hline $5 \mathrm{~s} 6 \mathrm{p}^{3} \mathrm{P}_{0}^{\mathrm{o}}$ & $1.81(1.55)^{\mathrm{a}}$ & $1.30 \pm 0.20$ & 3.04 & 1.54 \\
\hline $5 \mathrm{~s} 6 \mathrm{p}^{3} \mathrm{P}_{1}^{0}$ & $1.47(1.55)^{\mathrm{a}}$ & $1.30 \pm 0.20$ & 3.04 & 1.54 \\
\hline $5 \mathrm{~s} 6 \mathrm{p}^{3} \mathrm{P}_{2}^{1}$ & $1.56(1.55)^{\mathrm{a}}$ & $1.30 \pm 0.20$ & 3.04 & 1.54 \\
\hline $5 \mathrm{~s} 6 \mathrm{p}^{1} \mathrm{P}_{1}^{\mathrm{o}}$ & 1.00 & & & \\
\hline $5 s 4 f^{3} \mathrm{~F}_{2}^{\mathrm{o}}$ & $1.60(1.56)^{\mathrm{a}}$ & $2.0 \pm 0.4$ & 1.13 & 1.48 \\
\hline $5 \mathrm{~s} 4 \mathrm{f}^{3} \mathrm{~F}_{3}^{\mathrm{o}}$ & $1.56(1.56)^{\mathrm{a}}$ & $2.0 \pm 0.4$ & 1.13 & 1.48 \\
\hline $5 \mathrm{~s} 4 \mathrm{f}^{3} \mathrm{~F}_{4}^{\mathrm{o}}$ & $1.55(1.56)^{\mathrm{a}}$ & $2.0 \pm 0.4$ & 1.13 & 1.48 \\
\hline $5 \mathrm{~s} 4 \mathrm{f}^{1} \mathrm{~F}_{3}^{\mathrm{o}}$ & 0.91 & $1.37 \pm 0.20$ & 2.76 & 1.47 \\
\hline $5 \mathrm{p} 5 \mathrm{~d}^{3} \mathrm{~F}_{2}^{\mathrm{o}}$ & 0.48 & & & \\
\hline $5 \mathrm{~s} 6 \mathrm{~d}^{3} \mathrm{D}_{1}$ & $0.84(0.88)^{\mathrm{a}}$ & $0.90 \pm 0.20$ & 0.72 & 0.53 \\
\hline $5 \mathrm{~s} 6 \mathrm{~d}^{3} \mathrm{D}_{2}$ & $0.86(0.88)^{\mathrm{a}}$ & $0.90 \pm 0.20$ & 0.72 & 0.53 \\
\hline $5 \mathrm{~s} 6 \mathrm{~d}^{3} \mathrm{D}_{3}$ & $0.92(0.88)^{\mathrm{a}}$ & $0.90 \pm 0.20$ & 0.72 & 0.53 \\
\hline $5 s 6 d{ }^{1} D_{2}$ & 0.73 & $0.60 \pm 0.20$ & 1.03 & 0.49 \\
\hline $5 \mathrm{p} 5 \mathrm{~d}^{3} \mathrm{~F}_{3}^{\mathrm{o}}$ & 0.48 & & & \\
\hline $5 \mathrm{~s} 7 \mathrm{~s}^{3} \mathrm{~S}_{1}$ & 0.35 & & & \\
\hline $5 \mathrm{p} 5 \mathrm{~d}^{1} \mathrm{D}_{2}^{\mathrm{o}}$ & 0.26 & & & \\
\hline $5 \mathrm{~s} 7 \mathrm{~s}{ }^{1} \mathrm{~S}_{0}{ }^{2}$ & 0.41 & & & \\
\hline $5 \mathrm{p} 5 \mathrm{~d}^{3} \mathrm{~F}_{4}^{\mathrm{o}}$ & 0.52 & & & \\
\hline $5 \mathrm{p} 5 \mathrm{~d}^{3} \mathrm{D}_{1}^{\mathrm{o}}$ & 0.14 & & & \\
\hline $5 \mathrm{p} 5 \mathrm{~d}^{3} \mathrm{P}_{2}^{\mathrm{o}}$ & 0.17 & & & \\
\hline $5 \mathrm{p} 5 \mathrm{~d}^{3} \mathrm{P}_{0}^{\mathrm{o}}$ & 0.56 & & & \\
\hline $5 \mathrm{p} 5 \mathrm{~d}^{3} \mathrm{D}_{3}^{\mathrm{o}}$ & 0.13 & & & \\
\hline $5 \mathrm{p} 5 \mathrm{~d}^{3} \mathrm{P}_{1}^{\mathrm{o}}\left(5 \mathrm{~s} 7 \mathrm{p}{ }^{1} \mathrm{P}_{1}^{\mathrm{o}}\right)$ & 0.29 & & & \\
\hline $5 s 7 p^{1} \mathrm{P}_{1}^{\mathrm{o}}\left(5 \mathrm{~s} 7 \mathrm{p}^{3} \mathrm{P}_{1}^{\mathrm{o}}\right)$ & 0.36 & & & \\
\hline $5 \mathrm{p} 5 \mathrm{~d}^{3} \mathrm{D}_{2}^{\mathrm{o}}$ & 0.20 & & & \\
\hline $5 \mathrm{p} 6 \mathrm{~s}^{3} \mathrm{P}_{0}^{\mathrm{o}}\left(5 \mathrm{~s} 7 \mathrm{p}^{3} \mathrm{P}_{0}^{\mathrm{o}}\right)$ & 0.14 & & & \\
\hline $5 \mathrm{~s} 7 \mathrm{p}^{3} \mathrm{P}_{1}^{\mathrm{o}}$ & 0.19 & & & \\
\hline $5 \mathrm{~s} 5 \mathrm{f}^{1} \mathrm{~F}_{3}^{\mathrm{o}}$ & 0.45 & & & \\
\hline $5 s 7 p^{3} \mathrm{P}_{2}^{o}$ & 0.37 & & & \\
\hline $5 \mathrm{~s} 5 \mathrm{f}^{3} \mathrm{~F}_{3}^{\mathrm{o}}$ & 3.20 & & & \\
\hline $5 s 5 f^{3} \mathrm{~F}_{2}^{\mathrm{o}}$ & 3.11 & & & \\
\hline $5 \mathrm{~s} 5 \mathrm{f}^{3} \mathrm{~F}_{4}^{\mathrm{o}}$ & 3.73 & & & \\
\hline $5 \mathrm{~s} 7 \mathrm{p}^{3} \mathrm{P}_{0}^{\mathrm{o}}\left(5 \mathrm{p} 6 \mathrm{~s}^{3} \mathrm{P}_{0}^{\mathrm{o}}\right)$ & 0.66 & & & \\
\hline $5 \mathrm{p} 6 \mathrm{~s}^{3} \mathrm{P}_{1}^{\mathrm{o}}$ & 0.57 & & & \\
\hline $5 \mathrm{p} 5 \mathrm{~d}^{1} \mathrm{P}_{1}^{\mathrm{o}}$ & 0.31 & & & \\
\hline $5 \mathrm{p} 6 \mathrm{~s}^{3} \mathrm{P}_{2}^{\mathrm{o}}$ & 0.24 & & & \\
\hline $5 \mathrm{~s} 5 \mathrm{~g}^{1} \mathrm{G}_{4}$ & 0.87 & & & \\
\hline $5 \mathrm{~s} 5 \mathrm{~g}^{3} \mathrm{G}_{3}$ & 0.86 & & & \\
\hline $5 \mathrm{~s} 5 \mathrm{~g}^{3} \mathrm{G}_{4}$ & 0.86 & & & \\
\hline $5 \mathrm{~s} 5 \mathrm{~g}^{3} \mathrm{G}_{5}$ & 0.86 & & & \\
\hline $5 \mathrm{p} 5 \mathrm{~d}^{1} \mathrm{~F}_{3}^{\mathrm{o}}$ & 0.13 & & & \\
\hline
\end{tabular}

Table 2. (Continued.)

\begin{tabular}{lllll}
\hline State & $\tau_{\mathrm{RCI}}$ & $\tau_{\exp }^{\mathrm{a}}$ & $\tau_{C}^{\mathrm{a}}$ & $\tau_{\mathrm{HFR}}^{\mathrm{a}}$ \\
\hline $5 \mathrm{p} 6 \mathrm{~s}{ }^{1} \mathrm{P}_{1}^{\mathrm{o}}$ & 0.12 & & & \\
$5 \mathrm{~s} 8 \mathrm{~s}{ }^{3} \mathrm{~S}_{1}$ & 0.57 & & & \\
$5 \mathrm{~s} 8 \mathrm{~s}{ }^{1} \mathrm{~S}_{0}$ & 0.68 & & & \\
\hline
\end{tabular}

a The experimental and other theoretical lifetimes are term averaged. The reported values in parentheses are the term-averaged lifetimes from our RCI calculation.

velocity gauge. Overall, the different calculations agree very well. For $5 \mathrm{~s}^{2}{ }^{1} \mathrm{~S}_{0}-5 \mathrm{~s} 5 \mathrm{p}{ }^{1} \mathrm{P}_{1}^{\mathrm{o}}$, the theoretical transition rates seem to be somewhat larger than the rate derived from the beam-foil lifetime measurement by Pinnington et al [2].

Hyperfine-structure constants obtained from the RCI wavefunctions including spin polarization are displayed in table 5. Both diagonal and off-diagonal parameters are shown. The diagonal and off-diagonal constants show a similar convergence pattern, and are fairly stable after three layers of correlation orbitals.

In table 6 , the differences $\Delta S_{\mathrm{nms}}, \Delta S_{\mathrm{sms}}$ and $\Delta \rho(0)$ between the upper and lower state isotope shift parameters in the $5 \mathrm{~s}^{2}{ }^{1} \mathrm{~S}_{0}-5 \mathrm{~s} 5 \mathrm{p}{ }^{3} \mathrm{P}_{1}^{\mathrm{o}}$ transition are shown as functions of the increasing active set of orbitals. The computed quantities converge after three layers of correlation orbitals. Combining the computed differences in electronic quantities with differences in nuclear masses and charge radii according to equation (12), we obtain the isotope shift

$$
\begin{aligned}
\Delta v & =v_{123}-v_{121}=\underbrace{(0.1208)}_{\Delta v_{\mathrm{nms}}} \\
& +\underbrace{(0.3159)}_{\Delta v_{\mathrm{sms}}}+\underbrace{-1.0278}_{\Delta v_{\mathrm{vol}}}=-0.5911 \mathrm{GHz} .
\end{aligned}
$$

For the nuclear charge radii, we use the values proposed by Angeli [32] $\left\langle r_{121}^{2}\right\rangle=21.90427204 \mathrm{fm}^{2}$ and $\left\langle r_{123}^{2}\right\rangle=$ $21.97640641 \mathrm{fm}^{2}$. The nuclear masses were taken from the tables by Audi et al [33]. As expected for such a heavy system, the shift is dominated by the volume effect. To estimate the accuracy of the calculated isotope shift, we may look at the isotope shift for the $5 \mathrm{~s}^{2}{ }^{1} \mathrm{~S}_{0}-5 \mathrm{~s} 5 \mathrm{p}{ }^{3} \mathrm{P}_{1}^{\mathrm{o}}$ transition in In II. Calculations similar to the ones presented here predicted the ${ }^{115,113} \mathrm{In}$ isotope shift to be $-0.515 \mathrm{GHz}$ [30]. This should be compared with the most recent values of the shift that gives $-0.69576(0.168) \mathrm{GHz}$ [34], i.e. indicating an error of around $30 \%$ in the calculations. Provided that the difference in charge radii for $\mathrm{Sb}$ is known with the same accuracy as the difference in charge radii for In, we can expect that the calculated ${ }^{123,121} \mathrm{Sb}$ isotope shift is associated with an error of the same magnitude.

\subsection{The $5 \mathrm{~s}^{2}{ }^{1} \mathrm{~S}_{0}-5 \mathrm{~s} 5 \mathrm{p}{ }^{3} \mathrm{P}_{0}^{\mathrm{o}}$ hyperfine-induced transition}

The hyperfine interaction, although weak, not only shifts and splits individual $J$ levels, but also mixes wavefunctions with different $J$ quantum numbers. The wavefunction for the $5 \mathrm{~s} 5 \mathrm{p}^{3} \mathrm{P}_{0}^{\mathrm{o}}$ state can, when the hyperfine interaction is included, be written as

$$
\left|{ }^{‘} 5 \mathrm{~s} 5 \mathrm{p}^{3} \mathrm{P}_{0}^{\mathrm{o}} I F^{\prime}\right\rangle=c_{0}\left|5 \mathrm{~s} 5 \mathrm{p}^{3} \mathrm{P}_{0}^{\mathrm{o}} I F\right\rangle+\sum_{i} c_{i}\left|\gamma_{i} P J_{i} I F\right\rangle,
$$


Table 3. Weighted oscillator strengths and transition rates for spontaneous emission in units of $\mathrm{s}^{-1}$. Rates are based on computed transition energies. Length gauge has been used for E1 transitions. $R$ is the ratio between transition rates in length and velocity gauge. When the level designation does not agree with the one given by Rana et al [1], the designation from the latter work is given in parentheses.

\begin{tabular}{|c|c|c|c|c|c|c|}
\hline Upper & Lower & $\begin{array}{l}\Delta E_{\text {calc }} \\
\left(\mathrm{cm}^{-1}\right)\end{array}$ & $\lambda(\mathrm{nm})$ & $g f$ & A & $R$ \\
\hline $\mathrm{p}{ }^{1} \mathrm{P}_{1}^{\mathrm{o}}$ & ${ }^{2} \mathrm{~S}_{0}$ & 51 & 104.66 & $1.55 \mathrm{E}+00$ & $.15 \mathrm{E}+09$ & 0.93 \\
\hline${ }^{3} \mathrm{P}_{1}$ & $5 \mathrm{p}^{3} \mathrm{P}_{0}^{\mathrm{o}}$ & 91604 & 109.17 & $.52 \mathrm{E}-01$ & $1.03 \mathrm{E}+09$ & 0.94 \\
\hline $5 \mathrm{~s} 5 \mathrm{~d}^{3} \mathrm{D}_{1}$ & $5 \mathrm{~s} 5 \mathrm{p}^{3} \mathrm{P}_{0}^{\mathrm{o}}$ & 114160 & 87.60 & $9.39 \mathrm{E}-01$ & $2.72 \mathrm{E}+09$ & 0.96 \\
\hline $5 \mathrm{~s} 6 \mathrm{~s}^{3} \mathrm{~S}_{1}$ & $5 \mathrm{~s} 5 \mathrm{p}^{3} \mathrm{P}_{0}^{\mathrm{o}}$ & 124101 & 80.58 & $1.53 \mathrm{E}-01$ & $5.24 \mathrm{E}+08$ & 1.04 \\
\hline $5 \mathrm{p}^{2}{ }^{3} \mathrm{P}_{0}$ & $5 \mathrm{~s} 5 \mathrm{p}^{3} \mathrm{P}_{1}^{\mathrm{o}}$ & 85184 & 117.39 & $4.96 \mathrm{E}-01$ & $2.40 \mathrm{E}+09$ & 0.94 \\
\hline $5 p^{2}{ }^{1} D_{2}$ & $5 s 5 p^{3} \mathrm{P}_{1}^{o}$ & 89370 & 111.89 & $2.70 \mathrm{E}-01$ & $2.88 \mathrm{E}+08$ & 0.94 \\
\hline $5 p^{2}{ }^{3} P_{1}$ & $5 \mathrm{~s} 5 \mathrm{p}^{3} \mathrm{P}_{1}^{\mathrm{o}}$ & 89386 & 111.87 & $3.92 \mathrm{E}-01$ & $.97 \mathrm{E}+08$ & 0.94 \\
\hline $5 p^{2}{ }^{3} \mathrm{P}_{2}$ & $5 \mathrm{~s} 5 \mathrm{p}^{3} \mathrm{P}_{1}^{\mathrm{o}}$ & 96595 & 103.53 & $4.66 \mathrm{E}-01$ & $5.80 \mathrm{E}+08$ & 0.94 \\
\hline $5 s 5 d^{3} D_{1}$ & $5 s 5 p^{3} P_{1}^{o}$ & 111942 & 89.33 & $7.06 \mathrm{E}-01$ & $1.97 \mathrm{E}+09$ & 0.96 \\
\hline $5 \mathrm{~s} 5 \mathrm{~d}^{3} \mathrm{D}_{2}$ & $5 s 5 p^{3} \mathrm{P}_{1}^{\mathrm{o}}$ & 112291 & 89.05 & $2.09 \mathrm{E}+00$ & $3.52 \mathrm{E}+09$ & 0.96 \\
\hline $5 \mathrm{~s} 6 \mathrm{~s}^{3} \mathrm{~S}_{1}$ & $5 s 5 p^{3} \mathrm{P}_{1}^{\mathrm{o}}$ & 121884 & 82.05 & $4.77 \mathrm{E}-01$ & $1.58 \mathrm{E}+09$ & 1.03 \\
\hline $5 \mathrm{p}^{21} \mathrm{D}_{2}$ & $5 s 5 p^{3} \mathrm{P}_{2}^{0}$ & 83595 & 119.62 & $5.07 \mathrm{E}-01$ & $4.73 \mathrm{E}+08$ & 0.93 \\
\hline $5 p^{2}{ }^{3} \mathrm{P}_{1}$ & $5 s 5 p^{3} \mathrm{P}_{2}^{o}$ & 83611 & 119.60 & $5.89 \mathrm{E}-01$ & $9.16 \mathrm{E}+08$ & 0.93 \\
\hline $5 p^{2}{ }^{3} \mathrm{P}_{2}$ & $5 s 5 p^{3} \mathrm{P}_{2}^{\mathrm{o}}$ & 90820 & 110.11 & $1.41 \mathrm{E}+00$ & $1.55 \mathrm{E}+09$ & 0.94 \\
\hline $5 \mathrm{~s} 5 \mathrm{~d}^{3} \mathrm{D}_{2}$ & $5 s 5 p^{3} \mathrm{P}_{2}^{\mathrm{o}}$ & 106516 & 93.88 & $7.46 \mathrm{E}$ & $1.13 \mathrm{E}+09$ & 0.96 \\
\hline $5 s 5 d^{3} D_{3}$ & ${ }^{3} \mathrm{P}_{2}^{\mathrm{o}}$ & 107149 & 93.33 & $4.01 \mathrm{E}+00$ & $4.39 \mathrm{E}+09$ & 0.95 \\
\hline${ }^{3} \mathrm{~S}_{1}$ & ${ }^{3} \mathrm{P}_{2}^{\mathrm{o}}$ & 116 & 86. & $911 \mathrm{E}$ & $2.73 \mathrm{E}+09$ & 1.03 \\
\hline${ }^{3} \mathrm{~S}_{1}$ & $5 s 5 p^{3} P_{2}^{o}$ & 185 & & 01 & $09 \mathrm{E}+09$ & 1.05 \\
\hline $5 \mathrm{p}^{21} \mathrm{D}_{2}$ & $5 \mathrm{~s} 5 \mathrm{p}^{1} \mathrm{P}_{1}^{\mathrm{o}}$ & 60 & 164 & & $0 \mathrm{E}+08$ & 0.92 \\
\hline $5 \mathrm{p}^{2}{ }^{1} \mathrm{~S}_{0}$ & $5 \mathrm{~s} 5 \mathrm{p}^{1} \mathrm{P}_{1}^{\mathrm{o}}$ & 89 & & 01 & $09 E+09$ & 0.95 \\
\hline $5 \mathrm{~s} 5 \mathrm{~d}^{1} \mathrm{D}_{2}$ & & 98 & 1 & 0 & -09 & 0.95 \\
\hline & & 98 & & & & 1.02 \\
\hline & & 61 & & & -08 & 0.87 \\
\hline${ }^{3} \mathrm{D}_{1}^{\mathrm{o}}$ & & 110 & 9 & 00 & $12 \mathrm{E}+09$ & 0.96 \\
\hline $5 s 7 p^{1} P_{1}^{o}(5$ & & 3 & 85. & 01 & $43 \mathrm{E}+08$ & 1.01 \\
\hline $5 \mathrm{~s} 7 \mathrm{p}^{3} \mathrm{P}_{1}^{\mathrm{o}}$ & $5 p$ & 19 & 83. & $8 \mathrm{E}-01$ & $35 \mathrm{E}+08$ & 1.03 \\
\hline${ }^{1} \mathrm{P}_{1}^{\mathrm{o}}$ & ${ }^{1} \mathrm{D}_{2}$ & 62864 & 7 & $2.97 \mathrm{E}-01$ & $.62 \mathrm{E}+08$ & 1.04 \\
\hline${ }^{1} \mathrm{~F}_{3}^{\mathrm{o}}$ & $5 \mathrm{p}^{2}{ }^{1} \mathrm{D}_{2}$ & 72176 & $13 \xi$ & $1.43 \mathrm{E}+00$ & $7.09 \mathrm{E}+08$ & 0.95 \\
\hline${ }^{3} \mathrm{~F}_{2}^{\mathrm{o}}$ & $5 \mathrm{p}^{2}{ }^{1} \mathrm{D}_{2}$ & 97998 & 10 & 01 & $8.24 \mathrm{E}+08$ & 0.95 \\
\hline${ }^{3} \mathrm{~F}_{3}^{\mathrm{o}}$ & $5 \mathrm{p}^{2}{ }^{1} \mathrm{D}_{2}$ & 101728 & & 01 & +08 & 0.96 \\
\hline${ }^{1} D_{2}^{o}$ & $5 \mathrm{p}^{2}{ }^{1} \mathrm{D}_{2}$ & 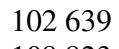 & & 0 & +09 & 0.95 \\
\hline${ }^{3} \mathrm{P}_{2}^{\mathrm{o}}$ & $5 \mathrm{p}^{2}{ }^{1} \mathrm{D}_{2}$ & 3 & & & +08 & 0.93 \\
\hline $5 \mathrm{p} 5 \mathrm{~d}^{3} \mathrm{D}_{3}^{\mathrm{o}}$ & $5 \mathrm{p}^{2}{ }^{1} \mathrm{D}_{2}$ & 112 & & 00 & +09 & 0.96 \\
\hline $5 \mathrm{p} 5 \mathrm{~d}^{3} \mathrm{P}_{1}^{\mathrm{o}}\left(5 \mathrm{~s} 7 \mathrm{p}{ }^{1} \mathrm{P}_{1}^{\mathrm{o}}\right)$ & $5 \mathrm{p}^{2}{ }^{1} \mathrm{D}_{2}$ & & & & & 1.03 \\
\hline $5 s 7 p^{1} \mathrm{P}_{1}^{\mathrm{o}}\left(5 \mathrm{~s} 7 \mathrm{p}^{3} \mathrm{P}_{1}^{\mathrm{o}}\right)$ & $5 \mathrm{p}^{2}{ }^{1} \mathrm{D}_{2}$ & 12 & & & +09 & 1.13 \\
\hline $5 \mathrm{p} 5 \mathrm{~d}^{3} \mathrm{D}_{2}^{\mathrm{o}}$ & $5 p^{2}{ }^{1} D_{2}$ & 12909 & & 01 & $4 \mathrm{E}+08$ & 0.96 \\
\hline $5 \mathrm{~s} 7 \mathrm{p}^{3} \mathrm{P}_{1}^{\mathrm{o}}$ & $5 \mathrm{p}^{2}{ }^{1} \mathrm{D}_{2}$ & & & 01 & $4.62 \mathrm{E}+08$ & 0.93 \\
\hline $5 \mathrm{~s} 7 \mathrm{p}^{3} \mathrm{P}_{2}^{\mathrm{o}}$ & $5 \mathrm{p}^{2}{ }^{1} \mathrm{D}_{2}$ & 5 & & $73 \mathrm{E}-01$ & $3.10 \mathrm{E}+08$ & 0.99 \\
\hline $5 \mathrm{p} 5 \mathrm{~d}^{1} \mathrm{P}_{1}^{\mathrm{o}}$ & $5 \mathrm{p}^{2}{ }^{1} \mathrm{D}_{2}$ & 122312 & & $1.28 \mathrm{E}-01$ & $4.26 \mathrm{E}+08$ & 0.91 \\
\hline $5 \mathrm{p} 6 \mathrm{~s}^{3} \mathrm{P}_{2}^{\mathrm{o}}$ & $5 \mathrm{p}^{2}{ }^{1} \mathrm{D}_{2}$ & 123626 & 80.89 & $2.58 \mathrm{E}-01$ & $5.26 \mathrm{E}+08$ & 1.04 \\
\hline $5 \mathrm{p} 5 \mathrm{~d}^{1} \mathrm{~F}_{3}^{\mathrm{o}}$ & $5 p^{2}{ }^{1} D_{2}$ & 129666 & 77. & $1.10 \mathrm{E}+00$ & $1.76 \mathrm{E}+09$ & 0.95 \\
\hline $5 \mathrm{p} 6 \mathrm{~s}{ }^{1} \mathrm{P}_{1}^{\mathrm{o}}$ & $5 \mathrm{p}^{2}{ }^{1} \mathrm{D}_{2}$ & 130857 & 76 . & $1.65 \mathrm{E}-01$ & $6.27 \mathrm{E}+08$ & 1.02 \\
\hline $5 \mathrm{p} 5 \mathrm{~d}^{1} \mathrm{D}_{2}^{\mathrm{o}}$ & $5 p^{2}{ }^{3} \mathrm{P}_{1}$ & 102622 & 97 & $9.18 \mathrm{E}-01$ & $1.29 \mathrm{E}+09$ & 0.97 \\
\hline${ }^{3} \mathrm{D}_{1}^{\mathrm{o}}$ & $5 p^{2}{ }^{3} \mathrm{P}_{1}$ & 06 & & $3.88 \mathrm{E}-01$ & $9.80 \mathrm{E}+08$ & 0.96 \\
\hline${ }^{3} \mathrm{P}_{2}^{\mathrm{o}}$ & $5 p^{23} \mathrm{P}_{1}$ & 08806 & & $2.52 \mathrm{E}+00$ & $3.98 \mathrm{E}+09$ & 0.96 \\
\hline${ }^{3} \mathrm{P}_{0}^{\mathrm{o}}$ & $5 p^{2}{ }^{3} \mathrm{P}_{1}$ & 0 & & $1.57 \mathrm{E}-01$ & $1 \mathrm{E}+09$ & 0.95 \\
\hline$\left.{ }^{1} \mathrm{P}_{1}^{\mathrm{o}}\right)$ & & & & & & 0.96 \\
\hline $5 \mathrm{p} 5 \mathrm{~d}^{3} \mathrm{D}_{2}^{\mathrm{o}}$ & $5 p^{2}{ }^{3} \mathrm{P}_{1}$ & & & 4.7 & -08 & 0.96 \\
\hline $5 \mathrm{p} 6 \mathrm{~s}^{3} \mathrm{P}_{0}^{\mathrm{o}}(5$ & $5 p^{23} P_{1}$ & & 87 & 6.74 & $5.86 \mathrm{E}+09$ & 1.01 \\
\hline $5 \mathrm{~s} 7 \mathrm{p}^{3} \mathrm{P}_{1}^{\mathrm{o}}$ & $5 p^{2}{ }^{3} \mathrm{P}_{1}$ & & 86.97 & $6.04 \mathrm{E}-01$ & $1.78 \mathrm{E}+09$ & 0.98 \\
\hline $5 \mathrm{p} 6 \mathrm{~s}^{3} \mathrm{P}_{2}^{\mathrm{o}}$ & $5 p^{23} P_{1}$ & 123610 & 80.90 & $3.24 \mathrm{E}-01$ & $6.60 \mathrm{E}+08$ & 1.04 \\
\hline $5 \mathrm{~s} 6 \mathrm{p}^{1} \mathrm{P}_{1}^{\mathrm{o}}$ & $5 p^{2}{ }^{3} \mathrm{P}_{2}$ & 55638 & 179.73 & $1.52 \mathrm{E}-01$ & $1.05 \mathrm{E}+08$ & 1.03 \\
\hline $5 \mathrm{~s} 4 \mathrm{f}^{1} \mathrm{~F}_{3}^{\mathrm{o}}$ & $5 p^{2}{ }^{3} P_{2}$ & 64950 & 153.96 & $5.96 \mathrm{E}-01$ & $2.40 \mathrm{E}+08$ & 0.96 \\
\hline $5 \mathrm{p} 5 \mathrm{~d}^{3} \mathrm{~F}_{3}^{\mathrm{o}}$ & $5 p^{2}{ }^{3} \mathrm{P}_{2}$ & 94503 & 105.82 & $1.93 \mathrm{E}-01$ & $1.65 \mathrm{E}+08$ & 0.95 \\
\hline $5 \mathrm{p} 5 \mathrm{~d}^{1} \mathrm{D}_{2}^{\mathrm{o}}$ & $5 p^{2}{ }^{3} \mathrm{P}_{2}$ & 95413 & 104.81 & $2.14 \mathrm{E}-01$ & $2.60 \mathrm{E}+08$ & 0.92 \\
\hline $5 \mathrm{p} 5 \mathrm{~d}^{3} \mathrm{P}_{2}^{\mathrm{o}}$ & $5 p^{2}{ }^{3} \mathrm{P}_{2}$ & 101598 & 98.43 & $2.23 \mathrm{E}-01$ & $3.07 \mathrm{E}+08$ & 0.96 \\
\hline $5 \mathrm{p} 5 \mathrm{~d}^{3} \mathrm{D}_{3}^{\mathrm{o}}$ & $5 p^{2}{ }^{3} \mathrm{P}_{2}$ & 104858 & 95.37 & $3.53 \mathrm{E}+00$ & $3.70 \mathrm{E}+09$ & 0.95 \\
\hline $5 \mathrm{p} 5 \mathrm{~d}^{3} \mathrm{P}_{1}^{\mathrm{o}}\left(5 \mathrm{~s} 7 \mathrm{p}{ }^{1} \mathrm{P}_{1}^{\mathrm{o}}\right)$ & $5 p^{2}{ }^{3} \mathrm{P}_{2}$ & 105126 & 95.12 & $1.54 \mathrm{E}-01$ & $3.79 \mathrm{E}+08$ & 0.91 \\
\hline $5 \mathrm{p} 5 \mathrm{~d}^{3} \mathrm{D}_{2}^{\mathrm{o}}$ & $5 p^{2}{ }^{3} \mathrm{P}_{2}$ & 105684 & 94.62 & $1.68 \mathrm{E}+00$ & $2.50 \mathrm{E}+09$ & 0.96 \\
\hline
\end{tabular}


Table 3. (Continued.)

\begin{tabular}{|c|c|c|c|c|c|c|}
\hline Upper & Lower & $\begin{array}{c}\Delta E_{\text {calc }} \\
\left(\mathrm{cm}^{-1}\right)\end{array}$ & $\lambda(\mathrm{nm})$ & $g f$ & $A$ & $R$ \\
\hline $7 \mathrm{n}^{3} \mathrm{P}^{\mathrm{o}}$ & ${ }^{3} \mathrm{P}_{2}$ & 7772 & 2.79 & $73 \mathrm{E}-01$ & $2 \mathrm{E}+09$ & 1.02 \\
\hline & ${ }^{3} \mathrm{P}_{2}$ & 98392 & 92.26 & $63 \mathrm{E}-01$ & $06 \mathrm{E}+08$ & 0.98 \\
\hline${ }^{3} \mathrm{P}_{2}^{\mathrm{o}}$ & $5 p^{2}{ }^{3} P_{2}$ & 08446 & 92.21 & $.31 E-01$ & $.31 E+09$ & 0.98 \\
\hline $5 \mathrm{p} 5 \mathrm{~d}^{1} \mathrm{P}_{1}^{\mathrm{o}}$ & ${ }^{3} \mathrm{P}_{2}$ & 115086 & 86.89 & $2.46 \mathrm{E}-01$ & $7.24 \mathrm{E}+08$ & 0.98 \\
\hline $5 \mathrm{p} 6 \mathrm{~s}^{3} \mathrm{P}_{2}^{\mathrm{o}}$ & $5 p^{2}{ }^{3} P_{2}$ & 116401 & 85.91 & $7.30 \mathrm{E}-01$ & $1.32 \mathrm{E}+09$ & 1.04 \\
\hline $5 \mathrm{p} 5 \mathrm{~d}^{1} \mathrm{~F}_{3}^{\mathrm{o}}$ & $5 p^{2}{ }^{3} P_{2}$ & 122441 & 81.67 & $6.65 \mathrm{E}-01$ & $9.50 \mathrm{E}+08$ & 0.95 \\
\hline $5 \mathrm{p} 6 \mathrm{~s}{ }^{1} \mathrm{P}_{1}^{\mathrm{o}}$ & $5 p^{2}{ }^{3} P_{2}$ & 123631 & 80.89 & $1.55 \mathrm{E}-01$ & $5.27 \mathrm{E}+08$ & 1.02 \\
\hline $5 \mathrm{~s} 6 \mathrm{p}^{3} \mathrm{P}_{0}^{\mathrm{o}}$ & $5 s 5 d^{3} D_{1}$ & 36685 & 272.59 & $3.97 \mathrm{E}-01$ & $3.57 \mathrm{E}+08$ & 1.03 \\
\hline$s 6 p^{3} \mathrm{P}_{1}^{\mathrm{o}}$ & $5 s 5 d^{3} D_{1}$ & 37026 & 270.08 & $2.58 \mathrm{E}-01$ & $7.87 \mathrm{E}+07$ & 1.03 \\
\hline $4 \mathrm{f}^{3} \mathrm{~F}_{2}^{\mathrm{o}}$ & $5 s 5 d^{3} D_{1}$ & 48307 & 207.01 & $1.69 \mathrm{E}+00$ & $5.27 \mathrm{E}+08$ & 1.00 \\
\hline $\mathrm{p} 5 \mathrm{~d}^{3} \mathrm{~F}_{2}^{\mathrm{o}}$ & $5 \mathrm{~s} 5 \mathrm{~d}^{3} \mathrm{D}_{1}$ & 75426 & 132.58 & $1.19 \mathrm{E}+00$ & $9.05 \mathrm{E}+08$ & 0.94 \\
\hline $5 \mathrm{~d}^{1} \mathrm{D}_{2}^{\mathrm{o}}$ & $5 s 5 d^{3} D_{1}$ & 80066 & 124.90 & $2.41 \mathrm{E}-01$ & $2.06 \mathrm{E}+08$ & 0.96 \\
\hline $05 d^{3} D_{1}^{o}$ & $5 s 5 d^{3} D_{1}$ & 84076 & 118.94 & $2.04 \mathrm{E}-01$ & $3.21 \mathrm{E}+08$ & 0.93 \\
\hline $5 \mathrm{~d}^{3} \mathrm{P}_{2}^{\mathrm{o}}$ & $5 s 5 d^{3} D_{1}$ & 86250 & 115.94 & $3.39 \mathrm{E}-01$ & $3.36 \mathrm{E}+08$ & 0.94 \\
\hline $5 d^{3} P_{1}^{o}\left(5 s 7 p^{1} P_{1}^{o}\right)$ & $5 s 5 d^{3} D_{1}$ & 89779 & 111.38 & $2.34 \mathrm{E}-01$ & $4.19 \mathrm{E}+08$ & 0.90 \\
\hline $5 d^{3} D_{2}^{o}$ & $5 s 5 d^{3} D_{1}$ & 90336 & 110.70 & $.91 \mathrm{E}-01$ & $.08 \mathrm{E}+08$ & 0.92 \\
\hline $7 p^{3} P_{1}^{o^{2}}$ & $5 s 5 d^{3} D_{1}$ & 92424 & 108.20 & $2.73 \mathrm{E}-01$ & $.19 \mathrm{E}+08$ & 0.99 \\
\hline $\mathrm{s}^{1} \mathrm{p}^{3} \mathrm{P}_{0}^{\mathrm{o}}\left(5 \mathrm{p} 6 \mathrm{~s}^{3} \mathrm{P}_{0}^{\mathrm{o}}\right)$ & $5 s 5 d^{3} D_{1}$ & 94021 & 106.36 & $1.59 \mathrm{E}-01$ & $.39 \mathrm{E}+08$ & 1.05 \\
\hline $5 \mathrm{~s} 6 \mathrm{p}^{3} \mathrm{P}_{1}^{\mathrm{o}}$ & $5 s 5 d^{3} D_{2}$ & 36678 & 272.64 & $7.83 \mathrm{E}-01$ & $34 \mathrm{E}+08$ & 1.03 \\
\hline $6 \mathrm{p}^{3} \mathrm{P}_{2}^{\mathrm{o}}$ & $5 s 5 d^{3} D_{2}$ & 38716 & 258.29 & $2.98 \mathrm{E}-01$ & $97 \mathrm{E}+07$ & 1.02 \\
\hline${ }^{1} \mathrm{P}_{1}^{\mathrm{o}}$ & $5 s 5 d^{3} D_{2}$ & 39942 & 250.36 & $1.07 \mathrm{E}-01$ & $81 \mathrm{E}+07$ & 1.03 \\
\hline${ }^{3} \mathrm{~F}_{2}^{\mathrm{o}}$ & $5 s 5 d^{3} D_{2}$ & 47958 & 2 & $3.03 \mathrm{E}$ & -07 & 1.00 \\
\hline${ }^{3} \mathrm{~F}_{3}^{\mathrm{o}}$ & $5 s 5 d^{3} D_{2}$ & 48 & & $2.50 \mathrm{E}+00$ & $9 \mathrm{E}+08$ & 1.00 \\
\hline $5 \mathrm{~d}^{3} \mathrm{~F}_{2}^{\mathrm{o}}$ & $5 d^{3} D_{2}$ & 75 & & 615 & $2 \mathrm{E}+08$ & 0.94 \\
\hline${ }^{3} \mathrm{~F}_{3}^{\mathrm{o}}$ & ${ }^{3} \mathrm{D}_{2}$ & 78 & & & E+09 & 0.94 \\
\hline & ${ }^{3} \mathrm{D}_{2}$ & $79^{\prime}$ & 4 & -01 & +08 & 0.92 \\
\hline & ${ }^{3} \mathrm{D}_{2}$ & 27 & 1 & 01 & -08 & 0.94 \\
\hline $\mathrm{D}_{3}^{\mathrm{O}}$ & ${ }^{3} \mathrm{D}_{2}$ & & & & & 0.94 \\
\hline & $\mathrm{D}_{2}$ & 37 & & -01 & & 0.92 \\
\hline $\mathrm{P}_{1}^{2}$ & ${ }^{3} \mathrm{D}_{2}$ & 92076 & 51 & $2.46 \mathrm{E}-01$ & +08 & 1.05 \\
\hline & ${ }^{3} \mathrm{D}_{2}$ & 92750 & 1 & $2.93 \mathrm{E}-01$ & $5+08$ & 1.01 \\
\hline${ }^{3} \mathrm{~F}_{3}^{\mathrm{o}}$ & ${ }^{3} \mathrm{D}_{2}$ & 93420 & .04 & $1.19 \mathrm{E}-01$ & $.87 \mathrm{E}+07$ & 0.94 \\
\hline${ }^{3} \mathrm{P}_{2}^{\mathrm{o}}$ & $d^{3} D_{3}$ & 38083 & 26 & $1.67 \mathrm{E}+00$ & $.23 E+08$ & 1.05 \\
\hline${ }^{3} \mathrm{~F}_{3}^{\mathrm{o}}$ & $5 s 5 d^{3} D_{3}$ & 86 & & $6 \mathrm{E}-01$ & & 1.00 \\
\hline${ }^{3} \mathrm{~F}_{4}^{\mathrm{o}}$ & $5 s 5 d^{3} D_{3}$ & & & $5 \mathrm{E}+00$ & -08 & 1.00 \\
\hline $\mathrm{d}^{3} \mathrm{~F}_{3}^{\mathrm{o}}$ & $5 s 5 d^{3} D_{3}$ & & & 01 & & 0.98 \\
\hline${ }^{1} \mathrm{D}_{2}^{\mathrm{o}}$ & $5 s 5 d^{3} D_{3}$ & & & -01 & -08 & 0.94 \\
\hline${ }^{3} \mathrm{~F}_{4}^{\mathrm{o}}$ & $5 s 5 d^{3} D_{3}$ & & & +00 & -09 & 0.96 \\
\hline${ }^{3} \mathrm{P}_{2}^{\mathrm{o}}$ & $5 s 5 d{ }^{3} D_{3}$ & & & $E-01$ & -08 & 0.92 \\
\hline $5 \mathrm{p} 5 \mathrm{~d}^{3} \mathrm{D}_{3}^{\mathrm{o}}$ & $5 s 5 d{ }^{3} D_{3}$ & & & -00 & -08 & 0.93 \\
\hline $5 \mathrm{~s} 7 \mathrm{p}^{3} \mathrm{P}_{2}^{\mathrm{o}}$ & $5 \mathrm{~s} 5 \mathrm{~d}^{3} \mathrm{D}_{3}$ & 117 & & 01 & +08 & 1.09 \\
\hline $5 \mathrm{f}^{3} \mathrm{~F}_{4}^{\circ}$ & $5 \mathrm{~s} 5 \mathrm{~d}^{3} \mathrm{D}_{3}$ & & & $1.68 \mathrm{E}-01$ & +08 & 0.92 \\
\hline $5 d^{1} P_{1}^{o}$ & $5 \mathrm{p}^{2}{ }^{1} \mathrm{~S}_{0}$ & 93290 & & $5.30 \mathrm{E}-01$ & $3 \mathrm{E}+09$ & 0.95 \\
\hline $66 s^{1} \mathrm{P}_{1}^{\mathrm{o}}$ & $5 \mathrm{p}^{2}{ }^{1} \mathrm{~S}_{0}$ & 101835 & 9 & $1.39 \mathrm{E}+00$ & $E+09$ & 0.99 \\
\hline $5 s 6 p^{3} P_{0}^{0}$ & $5 s 6 s^{3} S_{1}$ & & .92 & $4.12 \mathrm{E}-01$ & $97 \mathrm{E}+08$ & 1.01 \\
\hline $5 \mathrm{~s} 6 \mathrm{p}^{3} \mathrm{P}_{1}^{\mathrm{o}}$ & $5 s 6 s^{3} S_{1}$ & 27085 & 369.21 & $1.08 \mathrm{E}+00$ & $1.77 \mathrm{E}+08$ & 1.01 \\
\hline $5 \mathrm{~s} 6 \mathrm{p}^{3} \mathrm{P}_{2}^{\mathrm{o}}$ & $5 \mathrm{~s} 6 \mathrm{~s}^{3} \mathrm{~S}_{1}$ & 29123 & 343.37 & $2.23 \mathrm{E}+00$ & $2.52 \mathrm{E}+08$ & 1.01 \\
\hline $5 \mathrm{~s} 6 \mathrm{p}^{1} \mathrm{P}_{1}^{\mathrm{o}}$ & $5 s 6 s^{3} S_{1}$ & 30350 & 329.49 & $1.85 \mathrm{E}-01$ & $3.79 \mathrm{E}+07$ & 1.02 \\
\hline $5 s 7 p^{1} P_{1}^{o}\left(5 s 7 p^{3} P\right.$ & $5 s 6 s^{3} S_{1}$ & 80323 & 124.50 & $1.36 \mathrm{E}-01$ & $1.95 \mathrm{E}+08$ & 0.93 \\
\hline $5 \mathrm{p} 6 \mathrm{~s}^{3} \mathrm{P}_{0}^{\mathrm{o}}\left(5 \mathrm{~s} 7 \mathrm{p}^{3} \mathrm{P}_{0}^{\mathrm{o}}\right)$ & $5 s 6 s^{3} S_{1}$ & 81690 & 122.41 & $1.61 \mathrm{E}-01$ & $7.17 \mathrm{E}+08$ & 0.92 \\
\hline $5 s 7 p^{3} \mathrm{P}_{1}^{\mathrm{o}}$ & $5 s 6 s^{3} S_{1}$ & 82483 & 121.24 & $1.34 \mathrm{E}-01$ & $2.02 \mathrm{E}+08$ & 0.90 \\
\hline $5 \mathrm{~s} 7 \mathrm{p}^{3} \mathrm{P}_{0}^{\mathrm{o}}(5 \mathrm{p} 6$ & $5 \mathrm{~s}$ & 30 & 93 & $1.01 \mathrm{E}-01$ & $4 \mathrm{E}+08$ & 0.96 \\
\hline $5 \mathrm{p} 6 \mathrm{~s}^{3} \mathrm{P}_{1}^{\mathrm{o}}$ & ${ }^{3} \mathrm{~S}_{1}$ & & & & $78 \mathrm{E}+08$ & 0.96 \\
\hline $5 \mathrm{p} 5 \mathrm{~d}^{1} \mathrm{P}_{1}^{\mathrm{o}}$ & $5 \mathrm{~s} 6 \mathrm{~s}^{3} \mathrm{~S}_{1}$ & 9798 & 111.36 & $1.72 \mathrm{E}-01$ & $3.08 \mathrm{E}+08$ & 0.95 \\
\hline $5 \mathrm{p} 6 \mathrm{~s}^{3} \mathrm{P}_{2}^{\mathrm{o}}$ & $5 s 6 s^{3} S_{1}$ & 91112 & 109.76 & $1.42 \mathrm{E}+00$ & $.58 \mathrm{E}+09$ & 0.95 \\
\hline $5 s 6 p^{1} P_{1}^{0}$ & $5 s 5 d^{1} D_{2}$ & 25507 & 392.05 & $6.62 \mathrm{E}-01$ & $9.57 \mathrm{E}+07$ & 0.97 \\
\hline $5 \mathrm{~s} 4 \mathrm{f}^{1} \mathrm{~F}_{3}^{\mathrm{o}}$ & $5 \mathrm{~s} 5 \mathrm{~d}^{1} \mathrm{D}_{2}$ & 34819 & 287.20 & $1.08 \mathrm{E}+00$ & $1.25 \mathrm{E}+08$ & 1.08 \\
\hline $5 \mathrm{p} 5 \mathrm{~d}^{3} \mathrm{~F}_{3}^{\mathrm{o}}$ & $5 s 5 d^{1} D_{2}$ & 64371 & 155.35 & $1.81 \mathrm{E}-01$ & $7.13 \mathrm{E}+07$ & 0.96 \\
\hline $5 \mathrm{p} 5 \mathrm{~d}^{3} \mathrm{D}_{3}^{\mathrm{o}}$ & $5 s 5 d^{1} D_{2}$ & 74727 & 133.82 & $1.49 \mathrm{E}-01$ & $7.95 \mathrm{E}+07$ & 0.98 \\
\hline $5 \mathrm{~s} 5 \mathrm{f}^{1} \mathrm{~F}_{3}^{\mathrm{o}}$ & $5 s 5 d^{1} D_{2}$ & 78261 & 127.78 & $2.78 \mathrm{E}+00$ & $1.62 \mathrm{E}+09$ & 0.98 \\
\hline $5 \mathrm{p} 5 \mathrm{~d}^{1} \mathrm{~F}_{3}^{\mathrm{o}}$ & $5 s 5 d^{1} D_{2}$ & 92310 & 108.33 & $6.00 \mathrm{E}+00$ & $4.88 \mathrm{E}+09$ & 0.95 \\
\hline $5 \mathrm{p} 6 \mathrm{~s}{ }^{1} \mathrm{P}_{1}^{\mathrm{o}}$ & $5 \mathrm{~s} 5 \mathrm{~d}^{1} \mathrm{D}_{2}$ & 93500 & 106.95 & $1.16 \mathrm{E}+00$ & $2.26 \mathrm{E}+09$ & 0.99 \\
\hline $5 s 6 p^{3} P_{1}^{o}$ & $5 \mathrm{~s} 6 \mathrm{~s}{ }^{1} \mathrm{~S}_{0}$ & 21609 & 462.77 & $1.26 \mathrm{E}-01$ & $1.31 \mathrm{E}+07$ & 1.00 \\
\hline
\end{tabular}


Table 3. (Continued.)

\begin{tabular}{|c|c|c|c|c|c|c|}
\hline Upper & Lower & $\begin{array}{l}\Delta E_{\text {calc }} \\
\left(\mathrm{cm}^{-1}\right)\end{array}$ & $\lambda(\mathrm{nm})$ & $g f$ & $A$ & $R$ \\
\hline $6 n$ & $6 s{ }^{1} S_{0}$ & 3 & 4 & $06 \mathrm{E}-01$ & $\mathrm{E}+08$ & 1.01 \\
\hline $7 \mathrm{p}^{1} \mathrm{P}_{1}^{\mathrm{o}}\left(5 \mathrm{~s} 7 \mathrm{p}^{3} \mathrm{P}_{1}^{\mathrm{o}}\right)$ & $\mathrm{S}_{0}$ & 7 & & $86 \mathrm{E}-01$ & $56 \mathrm{E}+08$ & 0.97 \\
\hline $5 \mathrm{p} 5 \mathrm{~d}^{1} \mathrm{P}_{1}^{\mathrm{o}}$ & $5 \mathrm{~s} 6 \mathrm{~s}{ }^{1} \mathrm{~S}_{0}$ & 84321 & 118.59 & $.43 \mathrm{E}-01$ & $2.27 \mathrm{E}+08$ & 0.93 \\
\hline $5 \mathrm{p} 6 \mathrm{~s}{ }^{1} \mathrm{P}_{1}^{\mathrm{o}}$ & $5 \mathrm{~s} 6 \mathrm{~s}{ }^{1} \mathrm{~S}_{0}$ & 92866 & 107.68 & $.36 \mathrm{E}-01$ & $1.60 \mathrm{E}+09$ & 0.98 \\
\hline $5 \mathrm{~s} 6 \mathrm{~d}^{3} \mathrm{D}_{1}$ & $5 \mathrm{~s} 6 \mathrm{p}^{3} \mathrm{P}_{0}^{\mathrm{o}}$ & 39376 & 253.96 & $1.26 \mathrm{E}+00$ & $4.34 \mathrm{E}+08$ & 1.01 \\
\hline $5 \mathrm{~s} 7 \mathrm{~s}^{3} \mathrm{~S}_{1}$ & $5 \mathrm{~s} 6 \mathrm{p}^{3} \mathrm{P}_{0}^{\mathrm{o}}$ & 42480 & 235.40 & $2.58 \mathrm{E}-01$ & $.04 \mathrm{E}+08$ & 1.01 \\
\hline $5 s 6 d^{3} D_{1}$ & $5 \mathrm{~s} 6 \mathrm{p}^{3} \mathrm{P}_{1}^{\mathrm{o}}$ & 39035 & 256.18 & $.14 \mathrm{E}-01$ & $2.76 \mathrm{E}+08$ & 1.01 \\
\hline & $5 \mathrm{~s} 6 \mathrm{p}^{3} \mathrm{P}_{1}^{\mathrm{o}}$ & 39171 & 55.29 & $64 \mathrm{E}+00$ & $.40 \mathrm{E}+08$ & 1.01 \\
\hline & ${ }^{3} \mathrm{P}_{1}^{\mathrm{o}}$ & 41011 & 4 & 01 & $84 \mathrm{E}+07$ & 1.00 \\
\hline & $5 \mathrm{~s} 6 \mathrm{p}^{3} \mathrm{P}_{1}^{\mathrm{o}}$ & 42139 & 231.31 & $.81 \mathrm{E}$ & $2.69 \mathrm{E}+08$ & 1.01 \\
\hline & $5 s 6 p^{3} \mathrm{P}_{1}^{o}$ & 74849 & 0 & $1.10 \mathrm{E}-01$ & $.37 \mathrm{E}+08$ & 1.18 \\
\hline $5 \mathrm{~s} 6 \mathrm{~d}^{3} \mathrm{D}_{2}$ & $5 \mathrm{~s} 6 \mathrm{p}^{3} \mathrm{P}_{2}^{\mathrm{o}}$ & 37133 & 30 & $9.54 \mathrm{E}-01$ & $.76 \mathrm{E}+08$ & 1.01 \\
\hline $5 \mathrm{~s} 6 \mathrm{~d}^{3} \mathrm{D}_{3}$ & $5 s 6 p^{3} \mathrm{P}_{2}^{o}$ & 37412 & 29 & $5.41 \mathrm{E}+00$ & $.21 \mathrm{E}+08$ & 1.01 \\
\hline & ${ }^{3} \mathrm{P}_{2}^{\mathrm{o}}$ & 40101 & 49.37 & $1.43 \mathrm{E}+00$ & $.12 \mathrm{E}+08$ & 1.01 \\
\hline & ${ }^{3} \mathrm{P}_{2}^{\mathrm{o}}$ & 72810 & 34 & $2.11 \mathrm{E}-01$ & $.48 \mathrm{E}+08$ & 1.19 \\
\hline${ }^{3} \mathrm{D}_{1}$ & ${ }^{1} \mathrm{P}_{1}^{\mathrm{o}}$ & 35771 & 27 & $1.34 \mathrm{E}-01$ & $.81 \mathrm{E}+07$ & 1.01 \\
\hline${ }^{3} \mathrm{D}_{2}$ & ${ }^{1} \mathrm{P}_{1}^{\mathrm{o}}$ & 35 & 0 & $2.14 \mathrm{~B}$ & $\mathrm{E}+07$ & 1.01 \\
\hline${ }^{1} \mathrm{D}_{2}$ & ${ }^{1} \mathrm{P}_{1}^{\mathrm{o}}$ & 3 & & 0 & -08 & 1.00 \\
\hline${ }^{3} S_{1}$ & ${ }^{1} \mathrm{P}_{1}^{\mathrm{o}}$ & 3 & & 01 & 07 & 1.02 \\
\hline${ }^{1} \mathrm{~S}_{0}$ & $\mathrm{P}_{1}^{\mathrm{o}}$ & & & 1 & & 1.00 \\
\hline${ }^{1} \mathrm{~S}_{0}$ & $\mathrm{P}_{1}^{\mathrm{O}}$ & & & & & 1.09 \\
\hline${ }^{3} \mathrm{D}_{1}$ & & 2 & & & & 1.01 \\
\hline & & 54 & & 0 & & 1.01 \\
\hline & & 27 & & 1 & -07 & 1.00 \\
\hline & & 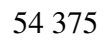 & & 3.1 & $0 \mathrm{E}+08$ & 1.01 \\
\hline & $\mathrm{F}_{3}^{\mathrm{o}}$ & 76 & & $3.08 \mathrm{E}-01$ & $.68 \mathrm{E}+07$ & 1.01 \\
\hline & ${ }^{3} \mathrm{~F}_{3}^{\mathrm{O}}$ & 54424 & & $1.70 \mathrm{E}+00$ & $3.72 \mathrm{E}+08$ & 1.01 \\
\hline & $\mathrm{F}_{4}^{\mathrm{O}}$ & 27 & & & & 1.00 \\
\hline & ${ }^{3} \mathrm{~F}_{4}^{\mathrm{o}}$ & 19 & & 01 & & 1.00 \\
\hline & $5 s 4 f^{3} \mathrm{~F}_{4}^{o}$ & & & & $3.60 \mathrm{E}+07$ & 1.01 \\
\hline & $5 \mathrm{~s} 4 \mathrm{f}^{3} \mathrm{~F}_{4}^{\mathrm{o}}$ & & & & & 1.01 \\
\hline${ }^{1} \mathrm{D}_{2}$ & ${ }^{1} \mathrm{~F}_{3}^{\mathrm{O}}$ & & & & & 1.03 \\
\hline & ${ }^{1} \mathrm{~F}_{3}^{\mathrm{o}}$ & & & & & 1.0 \\
\hline & ${ }^{1} \mathrm{~F}_{3}^{\mathrm{O}}$ & & & & & $1 .($ \\
\hline$d^{3} P_{0}^{o}$ & $5 s 6 d^{3} D_{1}$ & & & & & 1. \\
\hline$d^{3} P_{1}^{o}\left(5 s 7 p{ }^{1} P_{1}^{o}\right)$ & $5 s 6 d^{3} D_{1}$ & & & & -06 & 1.1 \\
\hline $5 \mathrm{~s} 7 \mathrm{p}^{3} \mathrm{P}_{1}^{\mathrm{o}}$ & $5 s 6 d^{3} D_{1}$ & & & $2.07 \mathrm{E}-01$ & $3 \mathrm{E}+07$ & 1. \\
\hline $5 s 5 f^{3} \mathrm{~F}_{2}^{\mathrm{o}}$ & $5 s 6 d^{3} D_{1}$ & & & $3.43 \mathrm{E}+00$ & $44 \mathrm{E}+08$ & $1 .($ \\
\hline $5 \mathrm{~s} 7 \mathrm{p}^{3} \mathrm{P}_{0}^{\mathrm{o}}\left(5 \mathrm{p} 6 \mathrm{~s}^{3} \mathrm{P}_{0}^{\mathrm{o}}\right)$ & $5 s 6 d^{3} D_{1}$ & & & $2.95 \mathrm{E}-01$ & $5 \mathrm{E}+07$ & 1.0 \\
\hline $5 \mathrm{p} 6 \mathrm{~s}^{3} \mathrm{P}_{1}^{\mathrm{o}}$ & $5 s 6 d^{3} D_{1}$ & 18820 & & $1.20 \mathrm{E}-01$ & $.43 \mathrm{E}+06$ & 1.0 \\
\hline $5 \mathrm{p} 5 \mathrm{~d}^{3} \mathrm{P}_{1}^{\mathrm{o}}\left(5 \mathrm{~s} 7 \mathrm{p}{ }^{1} \mathrm{P}_{1}^{\mathrm{o}}\right)$ & $5 s 6 d^{3} D_{2}$ & & & & & 1.13 \\
\hline $5 \mathrm{p} 5 \mathrm{~d}^{3} \mathrm{D}_{2}^{\mathrm{o}}$ & $5 s 6 d^{3} D_{2}$ & & & $1.21 \mathrm{E}-01$ & $E+06$ & 1.10 \\
\hline${ }^{3} \mathrm{P}_{1}^{2}$ & $5 s 6 d^{3} D_{2}$ & & & & $4.05 \mathrm{E}+07$ & 1.15 \\
\hline & $5 s 6 d^{3} D_{2}$ & 16 & & 01 & $E+07$ & 1.15 \\
\hline & $5 s 6 d^{3} D_{2}$ & & & 4 & $E+08$ & 1.08 \\
\hline & ${ }^{3} \mathrm{D}_{2}$ & 17 & & & $E+07$ & 1.07 \\
\hline & & & & & & 1.09 \\
\hline & & & & & & 1.23 \\
\hline & $\mathrm{D}_{3}$ & 16 & 5 & 2 & -07 & 1.1 \\
\hline & $5 s 6 d^{3} D_{3}$ & 17291 & .34 & $6.23 \mathrm{E}-01$ & +07 & 1.08 \\
\hline${ }^{3} \mathrm{~F}_{4}^{\mathrm{O}}$ & $5 s 6 d^{3} D_{3}$ & 17322 & 577.30 & $7.23 \mathrm{E}+00$ & $61 \mathrm{E}+08$ & 1.08 \\
\hline $5 \mathrm{p} 5 \mathrm{~d}^{3} \mathrm{P}_{1}^{\mathrm{o}}(5$ & $5 \mathrm{~s} 6 \mathrm{~d}^{1} \mathrm{D}_{2}$ & & & $1.31 \mathrm{E}-01$ & $4.02 \mathrm{E}+06$ & 1.01 \\
\hline $5 \mathrm{~s} 7 \mathrm{p}^{1} \mathrm{P}_{1}^{\mathrm{o}}\left(5 \mathrm{~s} 7 \mathrm{p}^{3} \mathrm{P}_{1}^{\mathrm{o}}\right)$ & $5 s 6 d^{1} D_{2}$ & 12225 & 818.00 & $9.78 \mathrm{E}-01$ & $3.25 \mathrm{E}+07$ & 1.07 \\
\hline $5 \mathrm{~s} 7 \mathrm{p}^{3} \mathrm{P}_{1}^{\mathrm{o}}$ & $5 s 6 d{ }^{1} D_{2}$ & 14386 & 695.12 & $1.38 \mathrm{E}-01$ & $6.36 \mathrm{E}+06$ & 0.93 \\
\hline $5 s 5 f^{1} \mathrm{~F}_{3}^{\mathrm{o}}$ & $5 s 6 d{ }^{1} D_{2}$ & 15006 & 666.40 & $4.00 \mathrm{E}+00$ & $8.58 \mathrm{E}+07$ & 1.06 \\
\hline $5 \mathrm{p} 6 \mathrm{~s}^{3} \mathrm{P}_{1}^{\mathrm{o}}$ & $5 \mathrm{~s} 6 \mathrm{~d}{ }^{1} \mathrm{D}_{2}$ & 16844 & 593.68 & $6.66 \mathrm{E}-01$ & $4.20 \mathrm{E}+07$ & 0.96 \\
\hline $5 \mathrm{p} 5 \mathrm{~d}^{1} \mathrm{P}_{1}^{\mathrm{o}}$ & $5 s 6 d{ }^{1} D_{2}$ & 21700 & 460.83 & $1.43 \mathrm{E}-01$ & $1.50 \mathrm{E}+07$ & 0.87 \\
\hline $\mathrm{d}^{1} \mathrm{~F}_{3}^{\mathrm{o}}$ & $5 \mathrm{~s} 6 \mathrm{~d}{ }^{1} \mathrm{D}_{2}$ & 29055 & 344.17 & $1.31 \mathrm{E}+00$ & $1.06 \mathrm{E}+08$ & 0.96 \\
\hline $5 \mathrm{p} 6 \mathrm{~s}{ }^{1} \mathrm{P}_{1}^{\mathrm{o}}$ & $5 s 6 d{ }^{1} D_{2}$ & 30245 & 330.63 & $1.34 \mathrm{E}-01$ & $2.73 \mathrm{E}+07$ & 0.87 \\
\hline & $5 p 5 d^{3} F_{3}^{o}$ & 23587 & 423.96 & $1.55 \mathrm{E}-01$ & $6.39 \mathrm{E}+06$ & 1.3 \\
\hline & & $10 ?$ & & $2.77 \mathrm{E}-01$ & $1.97 \mathrm{E}+07$ & 1.05 \\
\hline $5 \mathrm{p} 5 \mathrm{~d}^{3} \mathrm{P}_{1}^{\mathrm{o}}\left(5 \mathrm{~s} 7 \mathrm{p}{ }^{1} \mathrm{P}_{1}^{\mathrm{o}}\right)$ & $5 \mathrm{~s} 7 \mathrm{~s}^{3} \mathrm{~S}_{1}$ & 10613 & 942.24 & $5.93 \mathrm{E}-01$ & $1.49 \mathrm{E}+07$ & 1.05 \\
\hline
\end{tabular}


Table 3. (Continued.)

\begin{tabular}{|c|c|c|c|c|c|c|}
\hline Upper & Lower & $\begin{array}{l}\Delta E_{\text {calc }} \\
\left(\mathrm{cm}^{-1}\right)\end{array}$ & $\lambda(\mathrm{nm})$ & $g f$ & $A$ & $R$ \\
\hline $5 s 7 p^{1} \mathrm{P}_{1}^{o}\left(5 s 7 p^{3} \mathrm{P}_{1}^{o}\right)$ & $5 \mathrm{~s} 7 \mathrm{~s}{ }^{3} \mathrm{~S}_{1}$ & 11098 & 01.06 & $1.08 \mathrm{E}-01$ & $2.95 \mathrm{E}+06$ & 1.04 \\
\hline $5 \mathrm{p} 5 \mathrm{~d}^{3} \mathrm{D}_{2}^{\mathrm{o}}$ & $5 \mathrm{~s} 7 \mathrm{~s}^{3} \mathrm{~S}_{1}$ & 1170 & 895.26 & $40 \mathrm{E}-01$ & $1.07 \mathrm{E}+07$ & 1.06 \\
\hline $5 \mathrm{~s} 7 \mathrm{p}^{3} \mathrm{P}_{1}^{\mathrm{o}}$ & $5 \mathrm{~s} 7 \mathrm{~s}^{3} \mathrm{~S}_{1}$ & 13258 & 754.26 & $6.91 \mathrm{E}-01$ & $2.70 \mathrm{E}+07$ & 1.04 \\
\hline $5 s 7 p^{3} \mathrm{P}_{2}^{0}$ & $5 \mathrm{~s} 7 \mathrm{~s}^{3} \mathrm{~S}_{1}$ & 13933 & 717.72 & $2.37 \mathrm{E}+00$ & $6.13 \mathrm{E}+07$ & 1.03 \\
\hline $5 \mathrm{~s} 7 \mathrm{p}{ }^{3} \mathrm{P}_{0}^{\mathrm{o}}\left(5 \mathrm{p} 6 \mathrm{~s}^{3} \mathrm{P}_{0}^{\mathrm{o}}\right)$ & $5 \mathrm{~s} 7 \mathrm{~s}^{3} \mathrm{~S}_{1}$ & 14855 & 673.17 & $2.31 \mathrm{E}-01$ & $3.40 \mathrm{E}+07$ & 1.04 \\
\hline $5 \mathrm{p} 6 \mathrm{~s}^{3} \mathrm{P}_{1}^{\mathrm{o}}$ & $5 \mathrm{~s} 7 \mathrm{~s}^{3} \mathrm{~S}_{1}$ & 15716 & 636.29 & $3.79 \mathrm{E}-01$ & $2.08 \mathrm{E}+07$ & 1.04 \\
\hline $5 \mathrm{p} 5 \mathrm{~d}^{3} \mathrm{P}_{1}^{\mathrm{o}}\left(5 \mathrm{~s} 7 \mathrm{p}{ }^{1} \mathrm{P}_{1}^{\mathrm{o}}\right)$ & $5 \mathrm{~s} 7 \mathrm{~s}{ }^{1} \mathrm{~S}_{0}$ & 9008 & 1110.12 & $1.36 \mathrm{E}-01$ & $2.46 \mathrm{E}+06$ & 1.00 \\
\hline $5 s 7 p^{1} P_{1}^{o}\left(5 s 7 p^{3} P_{1}^{o}\right)$ & $5 \mathrm{~s} 7 \mathrm{~s}{ }^{1} \mathrm{~S}_{0}$ & 9494 & 1053.30 & $7.18 \mathrm{E}-01$ & $1.44 \mathrm{E}+07$ & 1.00 \\
\hline $5 \mathrm{~s} 7 \mathrm{p}^{3} \mathrm{P}_{1}^{\mathrm{o}}$ & $5 \mathrm{~s} 7 \mathrm{~s}{ }^{1} \mathrm{~S}_{0}$ & 11654 & 858.07 & $1.49 \mathrm{E}-01$ & $4.49 \mathrm{E}+06$ & 1.02 \\
\hline $5 \mathrm{p} 6 \mathrm{~s}^{3} \mathrm{P}_{1}^{\mathrm{o}}$ & $5 \mathrm{~s} 7 \mathrm{~s}{ }^{1} \mathrm{~S}_{0}$ & 14112 & 708.62 & $4.65 \mathrm{E}-01$ & $2.06 \mathrm{E}+07$ & 1.01 \\
\hline $5 \mathrm{p} 5 \mathrm{~d}^{1} \mathrm{P}_{1}^{\mathrm{o}}$ & $5 \mathrm{~s} 7 \mathrm{~s}{ }^{1} \mathrm{~S}_{0}$ & 18968 & 527.20 & $1.17 \mathrm{E}-01$ & $9.35 \mathrm{E}+06$ & 1.03 \\
\hline $5 \mathrm{p} 6 \mathrm{~s}{ }^{1} \mathrm{P}_{1}^{\mathrm{o}}$ & $5 \mathrm{~s} 7 \mathrm{~s}{ }^{1} \mathrm{~S}_{0}$ & 27513 & 363.46 & $1.19 \mathrm{E}-01$ & $2.01 \mathrm{E}+07$ & 1.00 \\
\hline $5 s 5 g^{3} \mathrm{G}_{5}$ & $5 p 5 d^{3} F_{4}^{o}$ & 18811 & 531.60 & $2.32 \mathrm{E}-01$ & $4.98 \mathrm{E}+06$ & 1.47 \\
\hline $5 s 8 s{ }^{3} S_{1}$ & $5 \mathrm{p} 5 \mathrm{~d}^{3} \mathrm{P}_{0}^{\mathrm{o}}$ & 22381 & 446.81 & $1.98 \mathrm{E}-01$ & $2.20 \mathrm{E}+07$ & 1.35 \\
\hline $5 s 5 g^{3} \mathrm{G}_{4}$ & $5 \mathrm{p} 5 \mathrm{~d}^{3} \mathrm{D}_{3}^{\mathrm{o}}$ & 13281 & 752.96 & $1.71 \mathrm{E}-01$ & $2.24 \mathrm{E}+06$ & 1.24 \\
\hline $5 s 8 s{ }^{3} S_{1}$ & $5 \mathrm{p} 5 \mathrm{~d}^{3} \mathrm{P}_{1}^{\mathrm{o}}\left(5 \mathrm{~s} 7 \mathrm{p}{ }^{1} \mathrm{P}_{1}^{\mathrm{o}}\right)$ & 22096 & 452.57 & $4.22 \mathrm{E}-01$ & $4.58 \mathrm{E}+07$ & 1.33 \\
\hline $5 \mathrm{~s} 8 \mathrm{~s}{ }^{1} \mathrm{~S}_{0}$ & $5 \mathrm{p} 5 \mathrm{~d}^{3} \mathrm{P}_{1}^{\mathrm{o}}\left(5 \mathrm{~s} 7 \mathrm{p}{ }^{1} \mathrm{P}_{1}^{\mathrm{o}}\right)$ & 22771 & 439.16 & $1.03 \mathrm{E}-01$ & $3.55 \mathrm{E}+07$ & 1.26 \\
\hline $5 \mathrm{~s} 8 \mathrm{~s}{ }^{1} \mathrm{~S}_{0}$ & $5 s 7 p^{1} P_{1}^{o}\left(5 s 7 p^{3} P_{1}^{o}\right)$ & 22286 & 448.71 & $5.58 \mathrm{E}-01$ & $1.85 \mathrm{E}+08$ & 1.33 \\
\hline $5 \mathrm{~s} 8 \mathrm{~s}{ }^{3} \mathrm{~S}_{1}$ & $5 \mathrm{p} 5 \mathrm{~d}^{3} \mathrm{D}_{2}^{\mathrm{o}}$ & 21539 & 464.27 & $4.66 \mathrm{E}-01$ & $4.81 \mathrm{E}+07$ & 1.38 \\
\hline $5 s 8 s^{3} S_{1}$ & $5 \mathrm{~s} 7 \mathrm{p}^{3} \mathrm{P}_{1}^{\mathrm{o}}$ & 19451 & 514.11 & $4.49 \mathrm{E}-01$ & $3.77 \mathrm{E}+07$ & 1.06 \\
\hline $5 \mathrm{~s} 8 \mathrm{~s}{ }^{1} \mathrm{~S}_{0}$ & $5 \mathrm{~s} 7 \mathrm{p}^{3} \mathrm{P}_{1}^{\mathrm{o}}$ & 20126 & 496.87 & $1.01 \mathrm{E}-01$ & $2.72 \mathrm{E}+07$ & 1.01 \\
\hline $5 \mathrm{~s} 5 \mathrm{~g}{ }^{1} \mathrm{G}_{4}$ & $5 s 5 f^{1} \mathrm{~F}_{3}^{\mathrm{o}}$ & 9698 & 1031.14 & $1.80 \mathrm{E}+00$ & $1.26 \mathrm{E}+07$ & 1.14 \\
\hline $5 \mathrm{~s} 5 \mathrm{~g}^{3} \mathrm{G}_{4}$ & $5 \mathrm{~s} 5 \mathrm{f}^{1} \mathrm{~F}_{3}^{\mathrm{o}}$ & 9747 & 1025.96 & $1.96 \mathrm{E}+00$ & $1.38 \mathrm{E}+07$ & 1.16 \\
\hline $5 s 8 s{ }^{3} S_{1}$ & $5 s 7 p^{3} \mathrm{P}_{2}^{o}$ & 18776 & 532.59 & $1.60 \mathrm{E}+00$ & $1.26 \mathrm{E}+08$ & 1.09 \\
\hline $5 \mathrm{~s} 5 \mathrm{~g}^{1} \mathrm{G}_{4}$ & $5 s 5 f^{3} \mathrm{~F}_{3}^{\mathrm{o}}$ & 8974 & 1114.33 & $1.94 \mathrm{E}+00$ & $1.16 \mathrm{E}+07$ & 1.13 \\
\hline $5 \mathrm{~s} 5 \mathrm{~g}^{3} \mathrm{G}_{3}$ & $5 \mathrm{~s} 5 \mathrm{f}^{3} \mathrm{~F}_{3}^{\mathrm{o}}$ & 8976 & 1114.08 & $2.45 \mathrm{E}-01$ & $1.88 \mathrm{E}+06$ & 1.13 \\
\hline $5 \mathrm{~s} 5 \mathrm{~g}^{3} \mathrm{G}_{4}$ & $5 \mathrm{~s} 5 \mathrm{f}^{3} \mathrm{~F}_{3}^{\mathrm{o}}$ & 9024 & 1108.16 & $1.75 \mathrm{E}+00$ & $1.06 \mathrm{E}+07$ & 1.13 \\
\hline $5 \mathrm{~s} 5 \mathrm{~g}^{3} \mathrm{G}_{3}$ & $5 s 5 f^{3} F_{2}^{o}$ & 8967 & 1115.20 & $2.82 \mathrm{E}+00$ & $2.16 \mathrm{E}+07$ & 1.13 \\
\hline $5 \mathrm{~s} 5 \mathrm{~g}^{1} \mathrm{G}_{4}$ & $5 \mathrm{~s} 5 \mathrm{f}^{3} \mathrm{~F}_{4}^{\mathrm{o}}$ & 8943 & 1118.19 & $1.20 \mathrm{E}-01$ & $7.12 \mathrm{E}+05$ & 1.13 \\
\hline $5 \mathrm{~s} 5 \mathrm{~g}^{3} \mathrm{G}_{4}$ & $5 s 5 f^{3} \mathrm{~F}_{4}^{\mathrm{o}}$ & 8992 & 1112.10 & $1.25 \mathrm{E}-01$ & $7.51 \mathrm{E}+05$ & 1.14 \\
\hline $5 \mathrm{~s} 5 \mathrm{~g}^{3} \mathrm{G}_{5}$ & $5 \mathrm{~s} 5 \mathrm{f}^{3} \mathrm{~F}_{4}^{\mathrm{o}}$ & 8994 & 1111.85 & $4.82 \mathrm{E}+00$ & $2.37 \mathrm{E}+07$ & 1.14 \\
\hline $5 s 8 s^{3} S_{1}$ & $5 \mathrm{~s} 7 \mathrm{p}^{3} \mathrm{P}_{0}^{\mathrm{o}}\left(5 \mathrm{p} 6 \mathrm{~s}^{3} \mathrm{P}_{0}^{\mathrm{o}}\right)$ & 17854 & 560.10 & $1.44 \mathrm{E}-01$ & $1.02 \mathrm{E}+07$ & 0.91 \\
\hline $5 s 8 s{ }^{3} S_{1}$ & $5 \mathrm{p} 6 \mathrm{~s}^{3} \mathrm{P}_{1}^{\mathrm{o}}$ & 16992 & 588.51 & $2.51 \mathrm{E}-01$ & $1.61 \mathrm{E}+07$ & 0.93 \\
\hline $5 \mathrm{~s} 8 \mathrm{~s}{ }^{1} \mathrm{~S}_{0}$ & $5 \mathrm{p} 6 \mathrm{~s}^{3} \mathrm{P}_{1}^{\mathrm{o}}$ & 17668 & 566.00 & $3.03 \mathrm{E}-01$ & $6.30 \mathrm{E}+07$ & 0.92 \\
\hline
\end{tabular}

Table 4. Energies (in $\mathrm{cm}^{-1}$ ) and rates in length and velocity gauges for the $5 \mathrm{~s}^{2}{ }^{1} \mathrm{~S}_{0}-5 \mathrm{~s} 5 \mathrm{p}{ }^{1} \mathrm{P}_{1}^{\mathrm{o}}$ and $5 \mathrm{~s}^{2}{ }^{1} \mathrm{~S}_{0}-5 \mathrm{~s} 5 \mathrm{p}{ }^{3} \mathrm{P}_{1,2}^{\mathrm{o}}$ transitions from RCI calculations with increasingly large configuration expansions. The first active set consists of the $5 \mathrm{~s}, 5 \mathrm{p}-, 5 \mathrm{p}, 5 \mathrm{~d}-, 5 \mathrm{~d}$ orbitals in the complex. The active set is enlarged by up to five layers of correlation orbitals.

\begin{tabular}{|c|c|c|c|c|c|c|}
\hline \multirow[b]{2}{*}{ Active set } & \multicolumn{3}{|c|}{$5 \mathrm{~s}^{2}{ }^{1} \mathrm{~S}_{0}-5 \mathrm{~s} 5 \mathrm{p}{ }^{1} \mathrm{P}_{1}^{\mathrm{o}} \mathrm{E} 1$} & \multicolumn{3}{|c|}{$5 s^{2}{ }^{1} S_{0}-5 s 5 p{ }^{3} P_{1}^{o} E 1$} \\
\hline & $\Delta E$ & $A_{L}$ & $A_{V}$ & $\Delta E$ & $A_{L}$ & $A_{V}$ \\
\hline Complex & 98037 & $5.893 E+9$ & $3.644 \mathrm{E}+9$ & 55536 & $6.501 E+7$ & $2.478 \mathrm{E}+6$ \\
\hline Layer 1 & 95316 & $3.342 \mathrm{E}+9$ & $3.141 \mathrm{E}+9$ & 65598 & $1.352 \mathrm{E}+7$ & $1.438 \mathrm{E}+7$ \\
\hline Layer 2 & 95673 & $3.201 \mathrm{E}+9$ & $3.372 \mathrm{E}+9$ & 66881 & $1.495 \mathrm{E}+7$ & $1.645 \mathrm{E}+7$ \\
\hline Layer 3 & 95613 & $3.178 \mathrm{E}+9$ & $3.386 \mathrm{E}+9$ & 66996 & $1.509 \mathrm{E}+7$ & $1.668 \mathrm{E}+7$ \\
\hline Layer 4 & 95597 & $3.167 E+9$ & $3.416 \mathrm{E}+9$ & 67004 & $1.506 \mathrm{E}+7$ & $1.696 \mathrm{E}+7$ \\
\hline Layer 5 & 95575 & $3.163 \mathrm{E}+9$ & $3.427 \mathrm{E}+9$ & 67005 & $1.506 \mathrm{E}+7$ & $1.705 \mathrm{E}+7$ \\
\hline $\mathrm{MCDHF}^{\mathrm{a}}$ & 95566 & $3.18 \mathrm{E}+9$ & $3.19 \mathrm{E}+9$ & 67283 & $1.42 \mathrm{E}+7$ & $1.54 \mathrm{E}+7$ \\
\hline $\mathrm{HFR}^{\mathrm{a}}$ & & $3.12 \mathrm{E}+9$ & & & $1.37 \mathrm{E}+7$ & \\
\hline $\operatorname{Exp}^{\mathrm{b}}$ & 95956.7 & $2.6 \pm 0.3 \mathrm{E}+9$ & & 66698.1 & & \\
\hline \multicolumn{7}{|c|}{$5 \mathrm{~s}^{2}{ }^{\mathrm{I}} \mathrm{S}_{0}-5 \mathrm{~s} 5 \mathrm{p}^{3} \mathrm{P}_{2}^{\mathrm{o}} \mathrm{M} 2$} \\
\hline Active set & $\Delta E$ & $A$ & & & & \\
\hline Complex & 61015 & $2.352 \mathrm{E}-2$ & & & & \\
\hline Layer 1 & 71338 & $5.850 \mathrm{E}-2$ & & & & \\
\hline Layer 2 & 72646 & $6.533 \mathrm{E}-2$ & & & & \\
\hline Layer 3 & 72764 & $6.600 \mathrm{E}-2$ & & & & \\
\hline Layer 4 & 72772 & $6.599 \mathrm{E}-2$ & & & & \\
\hline Layer 5 & 72773 & $6.600 \mathrm{E}-2$ & & & & \\
\hline Exp & 72560 & & & & & \\
\hline
\end{tabular}

\footnotetext{
a Biémont et al [6].
}

${ }^{\mathrm{b}}$ Pinnington et al [2]. 
Table 5. Magnetic dipole, $A$, and electric quadrupole, $B$, hyperfine interaction constants (in MHz) for $5 \mathrm{~s} 5 \mathrm{p}{ }^{3} \mathrm{P}^{\mathrm{o}}$ in ${ }^{121} \mathrm{Sb}$ from RCI calculations with increasingly large configuration expansions. The first active set consists of the $5 \mathrm{~s}, 5 \mathrm{p}-, 5 \mathrm{p}, 5 \mathrm{~d}-, 5 \mathrm{~d}$ orbitals in the complex. The active set is enlarged by up to five layers of correlation orbitals. The expansions include CSFs obtained by single excitations from all the core shells. We take the $I=5 / 2, \mu_{I}=3.363(3) \mathrm{nm}$ and $Q=-0.45(3)$ barn from the compilation by Stone [20].

\begin{tabular}{llllllll}
\hline Active set & $A\left({ }^{3} \mathrm{P}_{1}^{\mathrm{o}}\right)$ & $B\left({ }^{3} \mathrm{P}_{1}^{\mathrm{o}}\right)$ & $A\left({ }^{3} \mathrm{P}_{2}^{\mathrm{o}}\right)$ & $B\left({ }^{3} \mathrm{P}_{2}^{\mathrm{o}}\right)$ & $A\left({ }^{3} \mathrm{P}_{1}^{\mathrm{o}},{ }^{3} \mathrm{P}_{2}^{\mathrm{o}}\right)$ & $A\left({ }^{1} \mathrm{P}_{1}^{\mathrm{o}},{ }^{3} \mathrm{P}_{0}^{\mathrm{o}}\right)$ & $A\left({ }^{3} \mathrm{P}_{1}^{\mathrm{o}},{ }^{3} \mathrm{P}_{0}^{\mathrm{o}}\right)$ \\
\hline Complex & 12521 & 387 & 8866 & -696 & 10568 & 6870 & 10568 \\
Layer 1 & 13656 & 413 & 9137 & -757 & 10997 & 6992 & 10997 \\
Layer 2 & 13678 & 410 & 9110 & -754 & 10986 & 6882 & 10986 \\
Layer 3 & 13779 & 416 & 9168 & -765 & 11019 & 6912 & 11018 \\
Layer 4 & 13739 & 414 & 9138 & -762 & 10994 & 6891 & 10994 \\
Layer 5 & 13756 & 415 & 9150 & -764 & 11006 & 6898 & 11006 \\
\hline
\end{tabular}

where $I$ is the nuclear spin and $F(=I)$ is the total angular momentum quantum number. The use of quotation marks in the left-hand wavefunction emphasizes the fact that the notation is just a label indicating the dominant character of the eigenvector. Clearly, the one-photon $5 \mathrm{~s} 5 \mathrm{p}{ }^{3} \mathrm{P}_{0}^{\mathrm{o}} \rightarrow 5 \mathrm{~s}^{2}{ }^{1} \mathrm{~S}_{0}$ transition now becomes allowed via the mixing of functions with $J$ different from zero. $\left|5 \mathrm{~s} 5 \mathrm{p}{ }^{3} \mathrm{P}_{1}^{\mathrm{o}} I F\right\rangle$ and $\left|5 \mathrm{~s} 5 \mathrm{p}{ }^{1} \mathrm{P}_{1}^{\mathrm{o}} I F\right\rangle$ are the only important contributors to wavefunction expansion and in this work we model the $5 \mathrm{~s} 5 \mathrm{p}^{3} \mathrm{P}_{0}^{\mathrm{o}}$ state as

$$
\begin{aligned}
& \left|{ }^{‘ 5} 5 \mathrm{~s} 5{ }^{3} \mathrm{P}_{0}^{\mathrm{o}} I F\right\rangle=c_{0}\left|5 \mathrm{~s} 5 \mathrm{p}^{3} \mathrm{P}_{0}^{\mathrm{o}} I F\right\rangle \\
& \quad+c_{1}\left|5 \mathrm{~s} 5 \mathrm{p}{ }^{3} \mathrm{P}_{1}^{\mathrm{o}} I F\right\rangle+c_{2}\left|5 \mathrm{~s} 5 \mathrm{p}{ }^{1} \mathrm{P}_{1}^{\mathrm{o}} I F\right\rangle .
\end{aligned}
$$

The mixing coefficients are obtained by constructing and diagonalizing the Hamiltonian matrix in the presence of the hyperfine interaction. Once the mixing coefficients have been determined, the transition rate can be computed as

$$
\begin{aligned}
& A\left(5 \mathrm{~s} 5 \mathrm{p}{ }^{3} \mathrm{P}_{0}^{\mathrm{o}} \rightarrow 5 \mathrm{~s}^{2}{ }^{1} \mathrm{~S}_{0}\right) \\
& \quad=\frac{2.02613 \times 10^{18}}{3 \lambda^{3}} \mid c_{1}\left\langle 5 \mathrm{~s}^{2}{ }^{1} \mathrm{~S}_{0}\left\|\mathbf{Q}_{1}^{(1)}\right\| 5 \mathrm{~s} 5 \mathrm{p}^{3} \mathrm{P}_{1}^{\mathrm{o}}\right\rangle \\
& \quad+\left.c_{2}\left\langle 5 \mathrm{~s}^{2}{ }^{1} \mathrm{~S}_{0}\left\|\mathbf{Q}_{1}^{(1)}\right\| 5 \mathrm{~s} 5 \mathrm{p}{ }^{1} \mathrm{P}_{1}^{\mathrm{o}}\right\rangle\right|^{2},
\end{aligned}
$$

where the decay rate is in $s^{-1}$ and $\lambda$ is the wavelength in $\AA$ for the transition. $\left\langle 5 \mathrm{~s}^{2}{ }^{1} \mathrm{~S}_{0}\left\|\mathbf{Q}_{1}^{(1)}\right\| 5 \mathrm{~s} 5 \mathrm{p} \quad{ }^{3} \mathrm{P}_{1}^{\mathrm{o}}\right\rangle$ and $\left\langle 5 \mathrm{~s}^{2}{ }^{1} \mathrm{~S}_{0}\left\|\mathbf{Q}_{1}^{(1)}\right\| 5 \mathrm{~s} 5 \mathrm{p}{ }^{1} \mathrm{P}_{1}^{\mathrm{o}}\right\rangle$ are the reduced matrix elements for the electric dipole operator [19]. The reduced transition matrix elements can be obtained as square roots of the corresponding line strengths. The phase is such that we have constructive interference. To obtain a good value for the rate, both the hyperfine interaction and the transition matrix elements must be calculated with high accuracy. The off-diagonal magnetic hyperfine interaction constants needed to construct the Hamiltonian matrix elements are given in table 5. The reader may consult [29] for explicit formulas relating the interaction constants and the matrix elements. For ${ }^{121} \mathrm{Sb}$, the off-diagonal magnetic hyperfine interaction constants give the mixing coefficients $c_{1}=-4.908 \times 10^{-4}$ and $c_{2}=-2.212 \times 10^{-5}$. Using the transition matrix elements $\left\langle 5 \mathrm{~s}^{2}{ }^{1} \mathrm{~S}_{0}\left\|\mathbf{Q}_{1}^{(1)}\right\| 5 \mathrm{~s} 5 \mathrm{p}{ }^{3} \mathrm{P}_{1}^{\mathrm{o}}\right\rangle=2.722 \times 10^{-1}$ and $\left\langle 5 \mathrm{~s}^{2}{ }^{1} \mathrm{~S}_{0}\left\|\mathbf{Q}_{1}^{(1)}\right\| 5 \mathrm{~s} 5 \mathrm{p}{ }^{1} \mathrm{P}_{1}^{\circ}\right\rangle=2.316$ from the calculations reported in table 5 , we obtain a transition rate $A=6.278 \mathrm{~s}^{-1}$ corresponding to a lifetime $\tau=0.159 \mathrm{~s}$ of the ${ }^{3} \mathrm{P}_{0}^{\mathrm{o}}$ state. For ${ }^{123} \mathrm{Sb}$ with $I=7 / 2, \mu=2.5498$ (2) nm and $Q=0.49$ (5) barn, similar calculations give the rate $A=3.314 \mathrm{~s}^{-1}$ and lifetime $\tau=0.302 \mathrm{~s}$. To estimate the accuracy of the hyperfine-induced lifetime, we again rely on In II. Calculations similar to the ones
Table 6. Differences $\Delta S_{\mathrm{sms}}, \Delta S_{\mathrm{nms}}$ and $\Delta \rho(0)$ between the upper and lower state isotope shift parameters in the $5 \mathrm{~s}^{2}{ }^{1} \mathrm{~S}_{0}-5 \mathrm{~s} 5 \mathrm{p}{ }^{3} \mathrm{P}_{1}^{\mathrm{o}}$ transition from RCI calculations with increasingly large configuration expansions. The first active set consists of the $5 \mathrm{~s}, 5 \mathrm{p}-, 5 \mathrm{p}, 5 \mathrm{~d}-, 5 \mathrm{~d}$ orbitals in the complex. The active set is enlarged by up to five layers of correlation orbitals.

\begin{tabular}{llll}
\hline \multicolumn{4}{c}{$5 \mathrm{~s}^{2}{ }^{1} \mathrm{~S}_{0}-5 \mathrm{~s} 5 \mathrm{p}^{3} \mathrm{P}_{1}^{\mathrm{o}}$} \\
\hline Active set & $\Delta S_{\mathrm{sms}}$ & $\Delta \rho(0)$ & $\Delta S_{\mathrm{nms}}$ \\
\hline Complex & -0.359709 & -55.9264 & -0.244080 \\
Layer 1 & -0.766530 & -57.6157 & -0.180390 \\
Layer 2 & -0.657939 & -56.5270 & -0.238064 \\
Layer 3 & -0.687112 & -56.9699 & -0.202606 \\
Layer 4 & -0.645979 & -56.6869 & -0.248387 \\
Layer 5 & -0.650250 & -56.7749 & -0.248675 \\
\hline
\end{tabular}

presented here predicted a lifetime of $\tau=0.217 \mathrm{~s}$ of the ${ }^{3} \mathrm{P}_{0}^{\mathrm{o}}$ state in ${ }^{115} \mathrm{In}^{+}$. This is in excellent agreement with the most recent experimental value $\tau=0.195$ (8) s [35]. Based on the reasoning that the present calculation predicts hyperfine structure and transition rates with the same accuracy as in In II, we may expect the lifetimes of the ${ }^{3} \mathrm{P}_{0}^{\mathrm{o}}$ state in ${ }^{121} \mathrm{Sb}^{3+}$ and ${ }^{123} \mathrm{Sb}^{3+}$ to be quite accurate.

\section{Conclusion}

This work reports on extensive calculations for the level energies, lifetimes, Landé $g_{J}$-factors and transitions rates of the triply ionized antimony (Sb IV). Using the new release of GRASP2K [7], we describe 24 even-parity states, from $5 \mathrm{~s}^{2}{ }^{1} \mathrm{~S}_{0}$ to $5 \mathrm{~s} 8 \mathrm{~s}{ }^{1} \mathrm{~S}_{0}$, and 36 odd-parity states, from $5 \mathrm{~s} 5 \mathrm{p}{ }^{3} \mathrm{P}_{0}^{\mathrm{o}}$ to $5 \mathrm{p} 6 \mathrm{~s}{ }^{1} \mathrm{P}_{1}^{\mathrm{o}}$. The obtained theoretical data are in good agreement with available experimental data. There is also a good consistency with the theoretical calculations by Rana et al [1], although some problems of labelling remain due to the close degeneracy between odd-parity configurations. For testing the accuracy of our spectrum calculation, we perform separate calculations, for describing as best as possible the ground and first excited states. There is very good agreement for the predicted properties using either the spectrum or separated calculations. We use the highly correlated wavefunction from the calculations of the ground and first excited states for evaluating the isotope shift in the $5 \mathrm{~s}^{2}{ }^{1} \mathrm{~S}_{0}-5 \mathrm{~s} 5 \mathrm{p}{ }^{3} \mathrm{P}_{1}^{\mathrm{o}}$ transition and the rate of the hyperfine-induced $5 \mathrm{~s}^{2}{ }^{1} \mathrm{~S}_{0}-5 \mathrm{~s} 5 \mathrm{p}{ }^{3} \mathrm{P}_{0}^{\mathrm{o}}$ transition. 


\section{Acknowledgments}

Financial support by the Swedish Research Council is gratefully acknowledged. SV has a FRIA fellowship from the FRS-FNRS Fund for Scientific Research. Financial support by the Communauté française of Belgium (Action de Recherche Concertée) and the Belgian National Fund for Scientific Research (FRFC/IISN Convention) are gratefully acknowledged. GG and PJ acknowledge support from the Visby program of the Swedish Institute (SI).

\section{References}

[1] Rana T, Tauheed A and Joshi Y N 2001 Phys. Scr. 63108

[2] Pinnington E H, Ansbacher W, Kernahan J A, Gosselin R N, Bahr J L and Inamdar A S 1985 J. Opt. Soc. Am. B 21653

[3] Migdalek J and Baylis W E 1986 J. Phys. B: At. Mol. Phys. 191

[4] Chou H S, Chi H C and Huang K N 1993 Phys. Rev. A 482453

[5] Lavin C, Martin P, Martin I and Karwowski J 1993 Int. J. Quantum Chem. 27385

[6] Biémont E, Froese Fischer C, Godefroid M R, Palmeri P and Quinet P 2000 Phys. Rev. A 62032512

[7] Jönsson P, Gaigalas G, Bieroń J, Froese Fischer C and Grant I P 2012 Comput. Phys. Commun. to be submitted

[8] Jönsson P, He X, Froese Fischer C and Grant I P 2007 Comput. Phys. Commun. 177597

[9] Gaigalas G, Žalandauskas T and Rudzikas Z 2003 At. Data Nucl. Data Tables 8499

[10] Gaigalas G, Žalandauskas T and Fritzsche S 2004 Comput. Phys. Commun. 157239

[11] Grant I P 2007 Relativistic Quantum Theory of Atoms and Molecules (New York: Springer)

[12] McKenzie B J, Grant I P and Norrington P H 1980 Comput. Phys. Commun. 21233

[13] Dyall K G, Grant I P, Johnson C T, Parpia F A and Plummer E P 1989 Comput. Phys. Commun. 55425

[14] Gaigalas G, Fritzsche S and Grant I P 2001 Comput. Phys. Commun. 139263
[15] Jönsson P, Parpia F A and Froese Fischer C 1996 Comput. Phys. Commun. 96301

[16] Brink D M and Satchler G R 1968 Angular Momentum (Oxford: Clarendon)

[17] Indelicato P, Parente F and Marrus R 1989 Phys. Rev. A 403505

[18] Aboussaïd A, Godefroid M R, Jönsson P and Froese Fischer C 1995 Phys. Rev. A 512031

[19] Johnson W R, Cheng K T and Plante D R 1997 Phys. Rev. A 552728

[20] Stone N J 2005 At. Data Nucl. Data Tables 9075

[21] Froese Fischer C and Jönsson P 2001 J. Mol. Struct. 53755

[22] Andersson M and Jönsson P 2008 Comput. Phys. Commun. 178156

[23] Shabaev V M and Artemyev A N 1994 J. Phys. B: At. Mol. Opt. Phys. 271307

[24] Gaidamauskas E, Naze C, Rynkun P, Gaigalas G, Jönsson P and Godefroid M 2011 J. Phys. B: At. Mol. Opt. Phys. 44175003

[25] Nazé C, Gaidamauskas E, Gaigalas G, Godefroid M, Jönsson P and Li J 2012 Comput. Phys. Commun. to be submitted

[26] Grant I P 1974 J. Phys. B: At. Mol. Phys. 71458

[27] Olsen J, Godefroid M, Jönsson P, Malmqvist P $\AA$ and Froese Fischer C 1995 Phys. Rev. E 524499

[28] Jönsson P and Froese Fischer C 1998 Phys. Rev. A 574967

[29] Froese Fischer C, Brage T and Jönsson P 1997 Computational Atomic Structure-An MCHF Approach (Bristol: Institute of Physics Publishing)

[30] Jönsson P and Andersson M 2007 J. Phys. B: At. Mol. Opt. Phys. 402417

[31] Ynnerman A and Froese Fischer C 1995 Phys. Rev. A 512020

[32] Angeli I 2004 At. Data Nucl. Data Tables 87185

[33] Audi G, Wapstra A H and Thibaul C 2003 Nucl. Phys. 729337

[34] Wang Y H, Dumke R, Zhang J, Liu T, Stejskal A, Zhao Y N, Lu Z H, Wang L J, Becker T and Walther H 2007 Eur. Phys. J. D 44307

[35] Becker T, Zanthier J v, Nevsky A Y, Schwedes C, Skvortsov M N, Walther H and Peik E 2001 Phys. Rev. A 63051802 